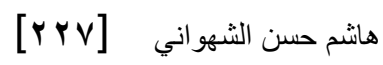

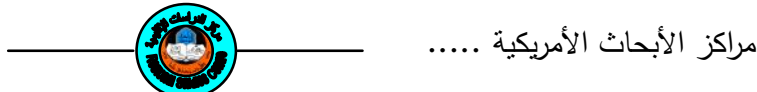

مراكز الأبحاث الأمريكية (Think Tanks)

وأثرها في السياسة الخارجية الأمريكية إزاء القضايا العربية

$$
\text { هاشم حسن حسين الثهواني }
$$

مدرس مساعد، قسم الدراسات الثاريخية والثقافية/ مركز الدراسات الإقليمية/

جامعة الموصل

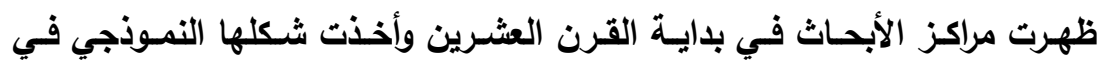

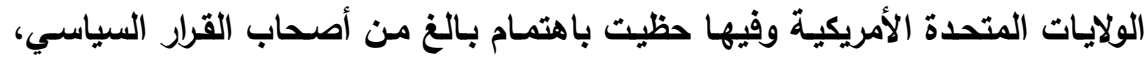

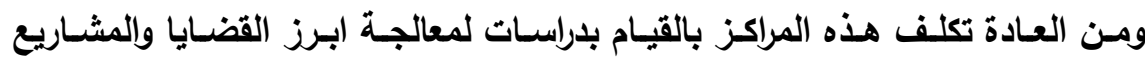

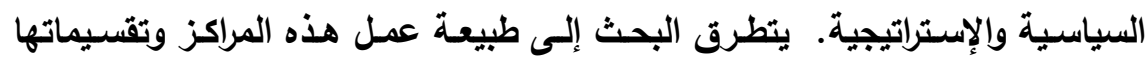

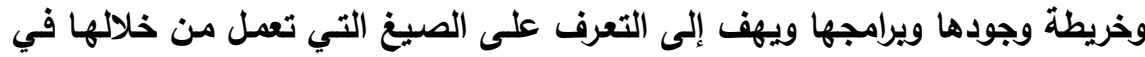

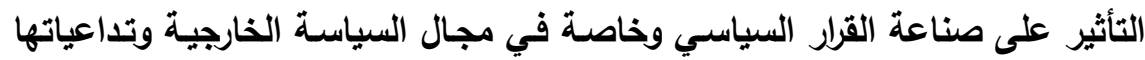
فيما يتطلق بالمنطقة العربية وتأثيرها في السياسة الأمريكية حيالها.

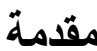

مارست الولايات المتحدة الأمريكية في أعقاب الحرب العالمية الثانية دورا محوريا في السياسة الدولية، وقد ازداد هذا الدور أهمية ومركزية بعد الهيات الهيار

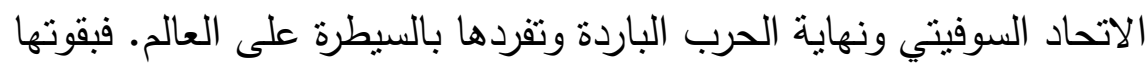

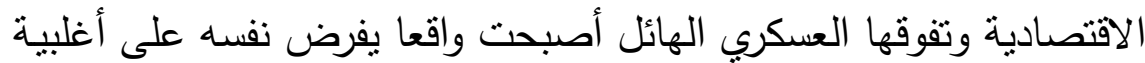

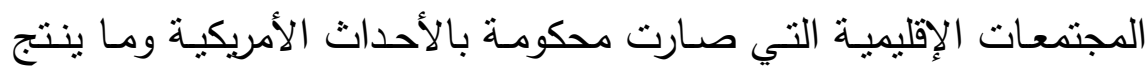

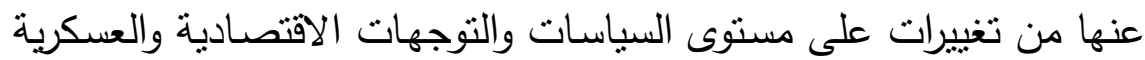

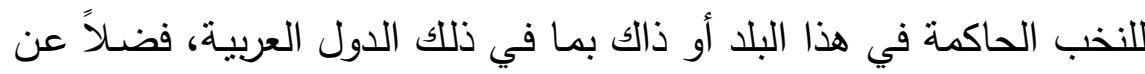

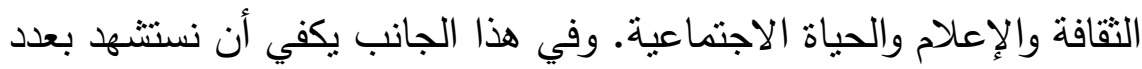

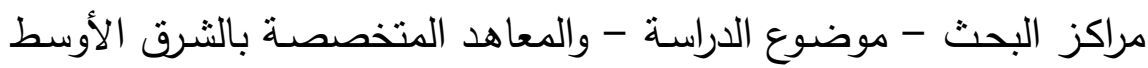

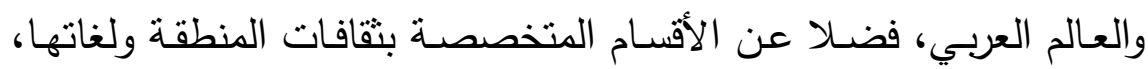

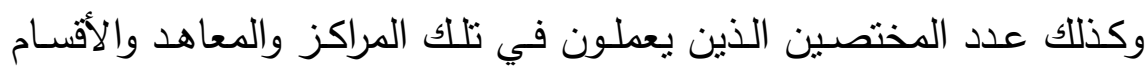


وعدد الدارسين وما ينتج عن هذا كله من أبحاث ورسائل جامعية وكتب.

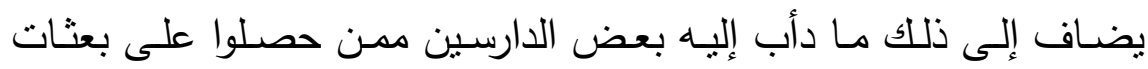

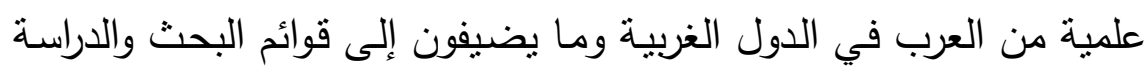
من رسائل جامعية وأبحاث في مختلف الجامعات الأمريكية، من شأنه تعزيز المعرفة بالعالم العربي وحضوره الثقافي لدى صانع القرار الأمريكي.

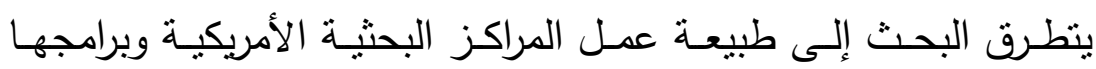
وأهدافها سيما فيما يتعلق بالمنطقة العربية ونأثيرها في السياسـة الأمريكية حيالها.

أمسا هيكليته فتتاولت نلك المراكز مـن حيث خريطة وجودهـا وتمويلها

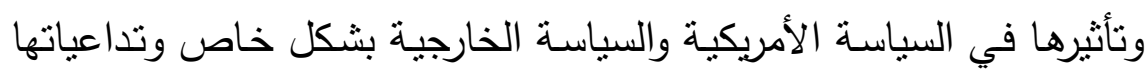

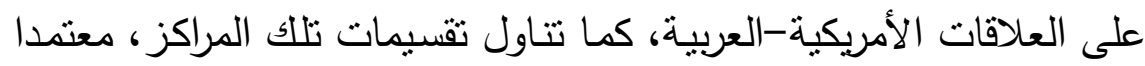
على أهم ما كتب حول الموضوع من مقالات وكتابات منشورة ومناحة على شبكة المعلومات العالمية نظرا لمحدودية ما كتب في هذا الموضوع.

\section{أهمية مراكز الأبحاث}

تعد المراكز البحثبة أو ما يطلق عليه Think-Tanks من أبرز سمات الات مرات

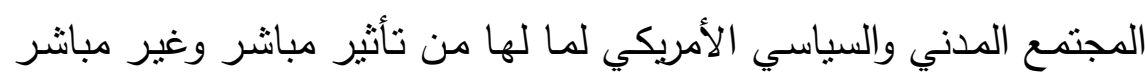
على مراكز صنع القرار في الولايات المتحدة، سواء على المستوى الداخلي

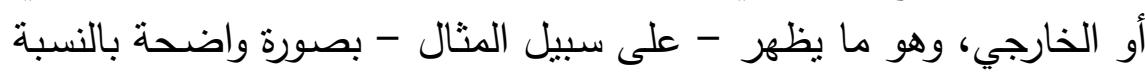
للسياسة الخارجية الأمريكية في العالم. بدايـة، فإن دور تلك المراكز في صياغة السياسـة الخارجيـة الأمريكية

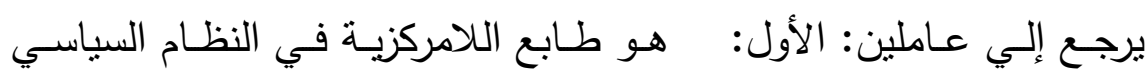

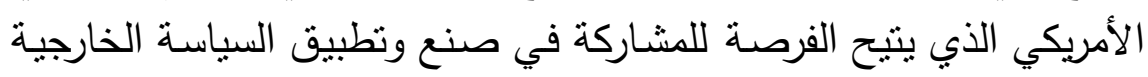

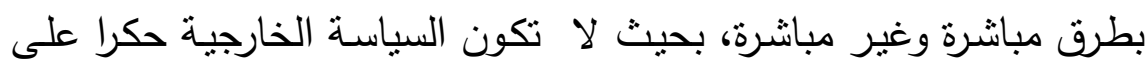

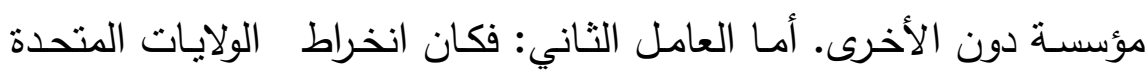




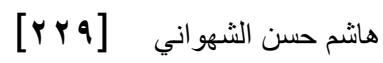

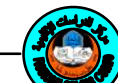

كفاعل رئيس في العلاقات الدولية منذ بداية القرن العشرين، وتطور هذا

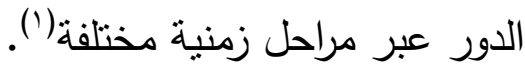
وفي إطار كل هذه الاعنبارات مُتثار العديد من التساؤلات حول طبيعة

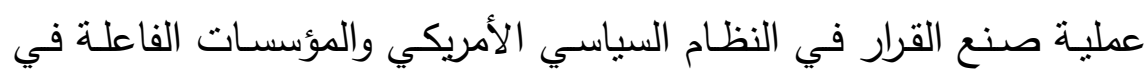

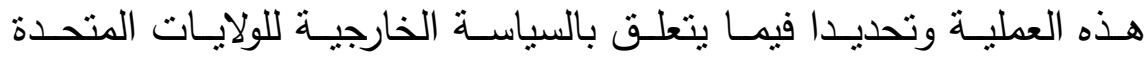

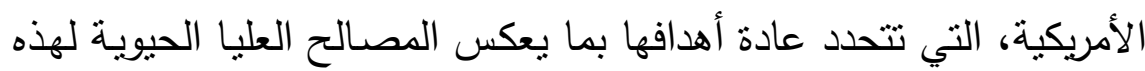

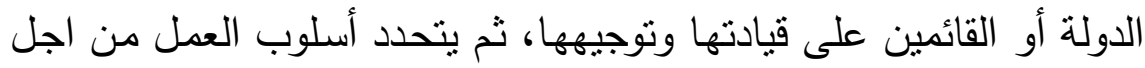

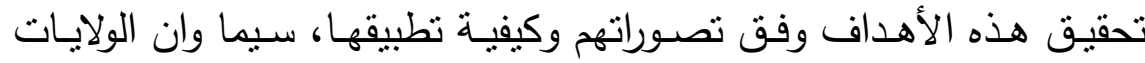

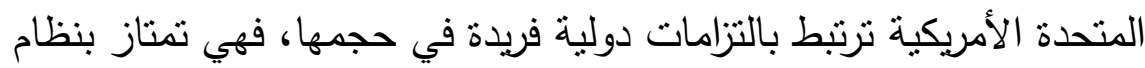

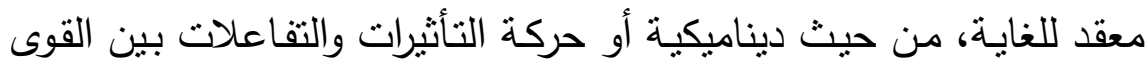

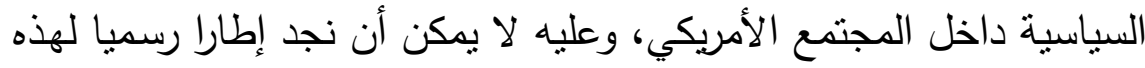

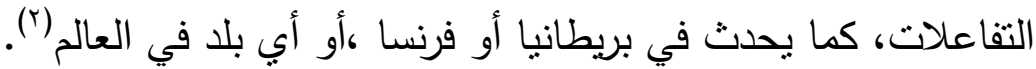

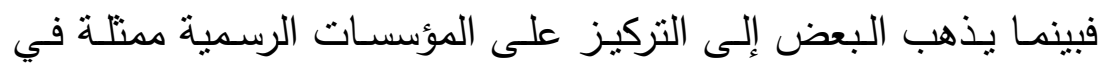

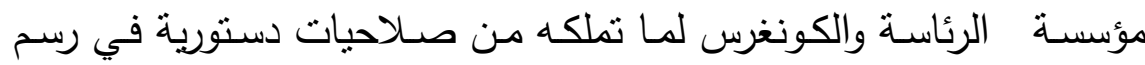

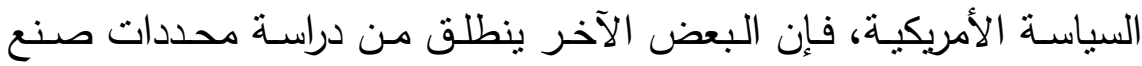

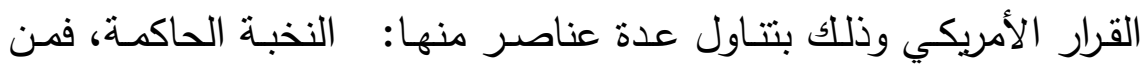

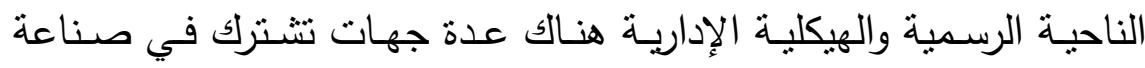

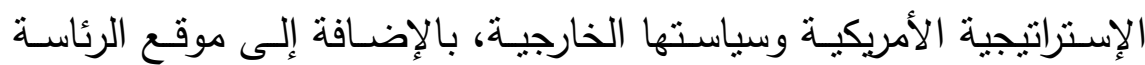

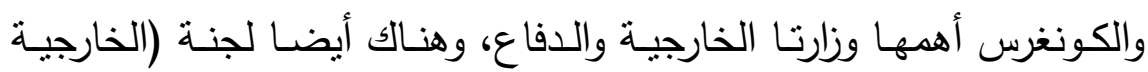

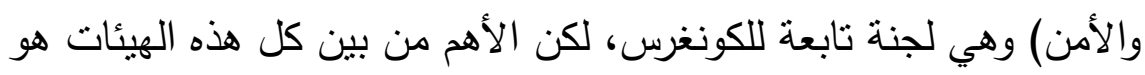

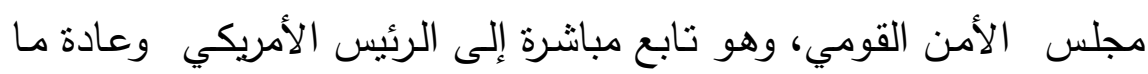

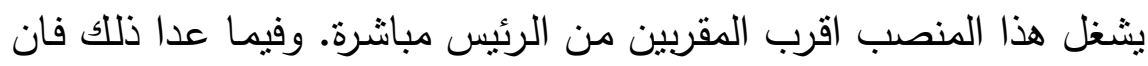

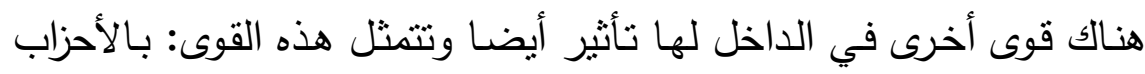

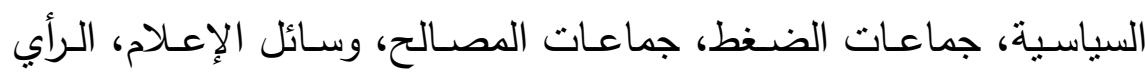




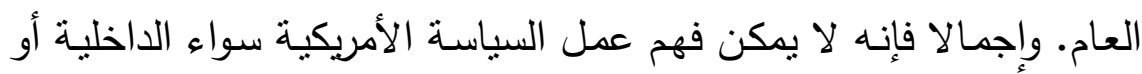

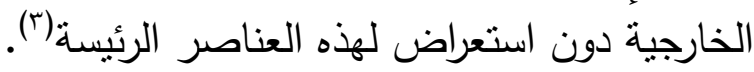
ومن بين تلك العناصر توجد مؤسسات ضخمة تعنى بالفكر الإستراتيجي

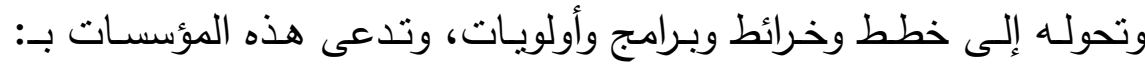

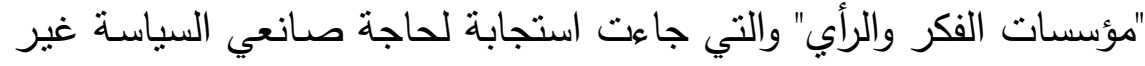

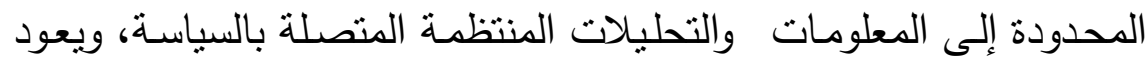

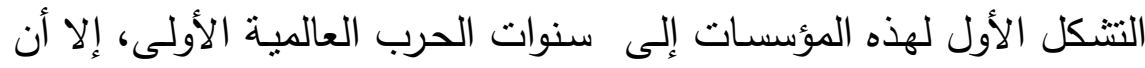

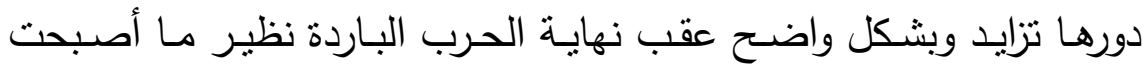

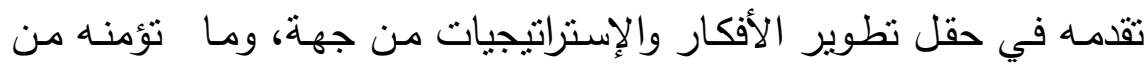

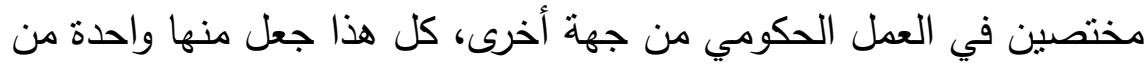

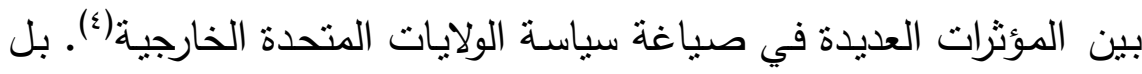

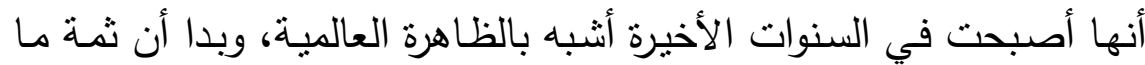

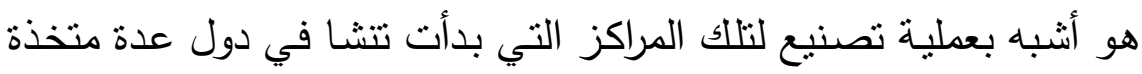

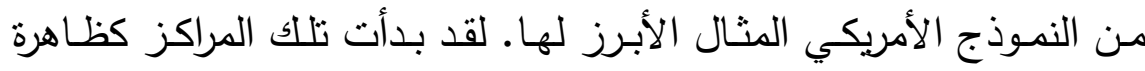

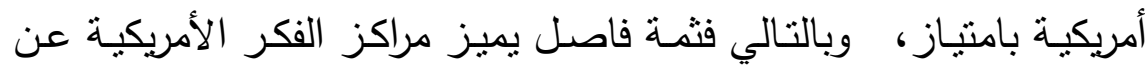

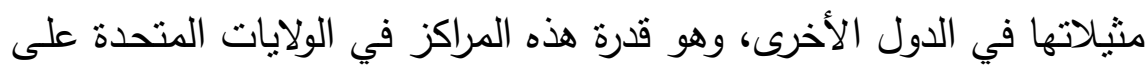

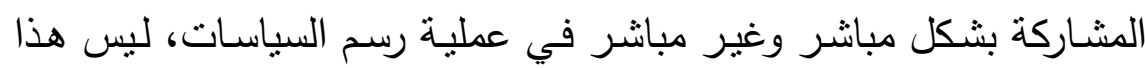

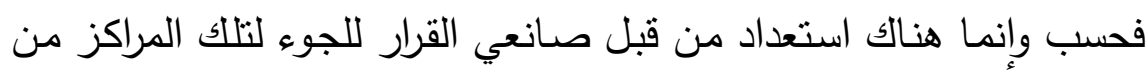

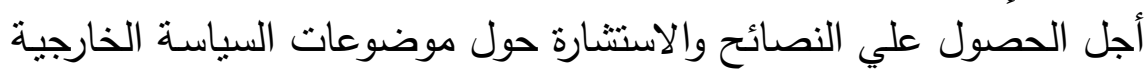

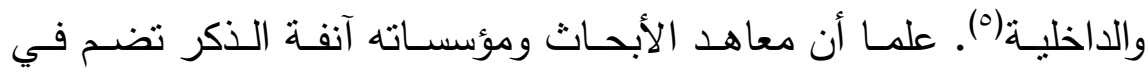

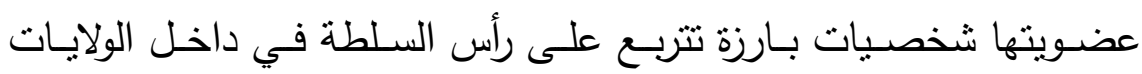
المتحدة:(7). 


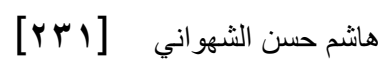

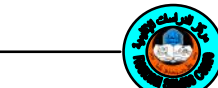

تُعرِّنْ أغلب المراكز الفكرية في الولايات المتحدة عن نفسها على أنها

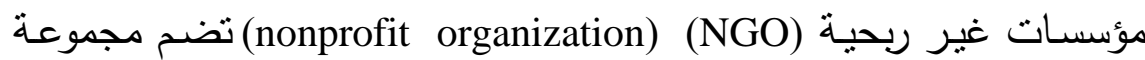
متخصصة من الأكاديميين والسياسيين يشتركون في الاهتمام بمجموعة من فن المواقف والقضايا السياسية العامة، ويعملون بشكل منظم من أجل التعريف بهذه القضايا، وزيادة الوعي بجوانبها المتعددة، وفيما عدا ذلك فإن الكثير

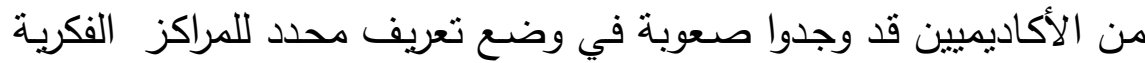
في ألبلاد، بل إن بعض الباحثين يرى عدم إمكانية وجود تعريف واحد يجمع

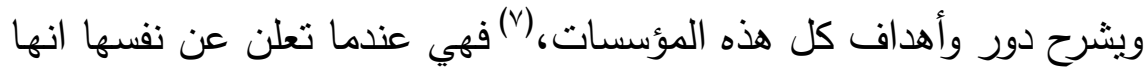

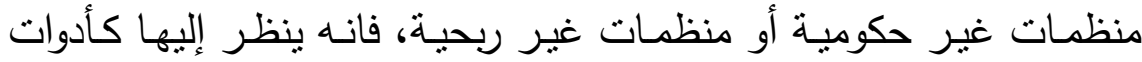

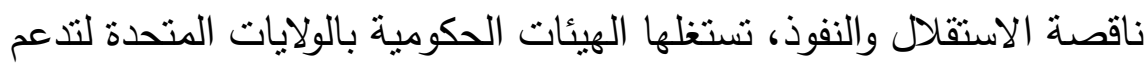
أجندة الحكومة المركزية الأمريكية، لكن على الرغم من كل هذه الإثشكاليات

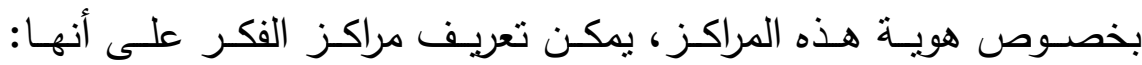

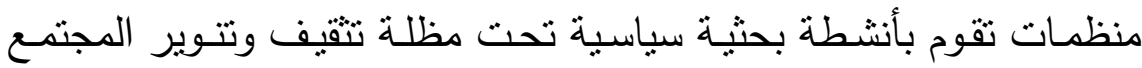

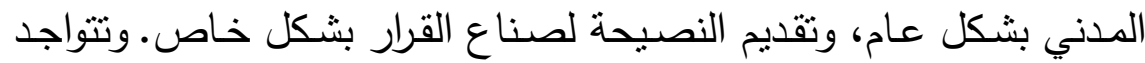

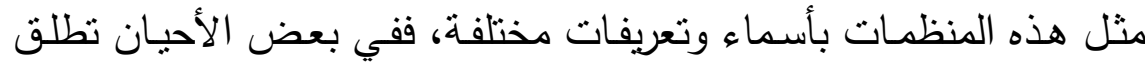
على نفسها مؤسسـة (Foundation) وفي بعض الأحيان معهد (Institute)

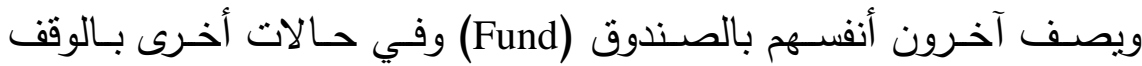
(^) (Endowment) يعرّف معجم وبستر (webster dictionary) المركـز الفكري بأنسه:

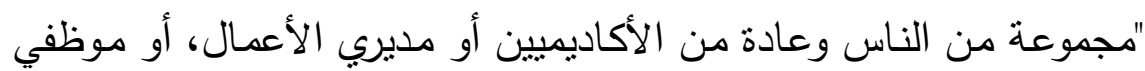

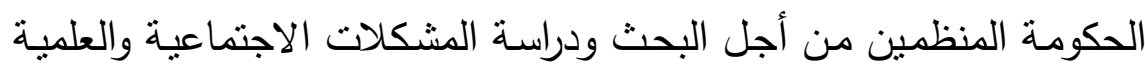
وغيرها". أما معجم التراث الأمريكي (American heritage dictionary)

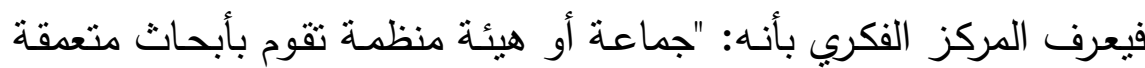

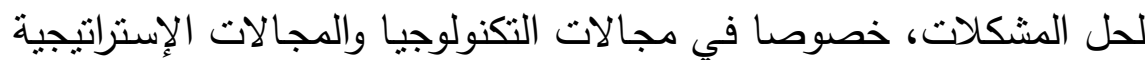
أو الاجتماعية أو السياسية أو التسلح" (9). 
ويعرّف معجم العلاقات الدولية المركز الفكري بأنه: "معهد أبحاث ممول على نحو مستقل ويهتم بدراسـة العلاقات الدولية ومجالات قضـايا السياسـة الخارجيـة". وتعرف الموسوعة الدوليـة للعلوم الاجتماعيـة والسلوكية المركز

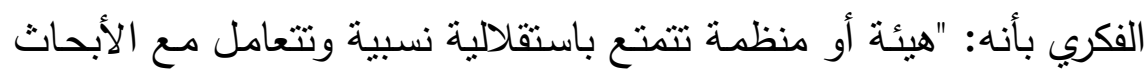

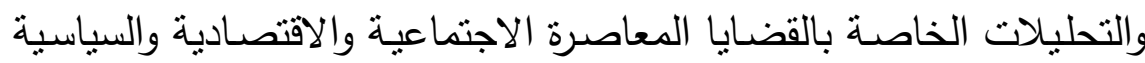

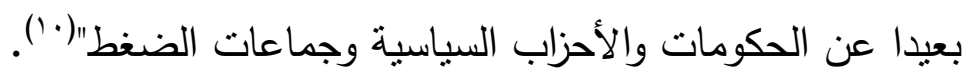

\section{ظهور مراكز الأبحاث}

ظهرت مراكز الأبحـاث في الولايـات المتحدة الأمريكيـة إلى حد كبيـر

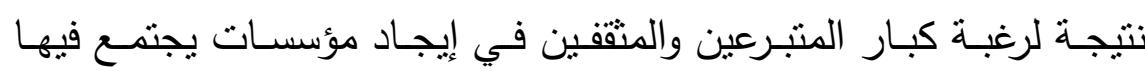

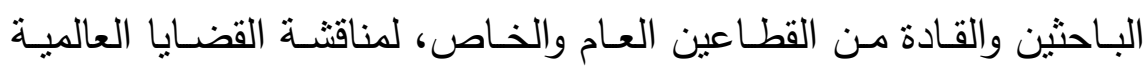
والتداول بشأنها، وقد بدأ عدد من المؤسسات بنوع خاص بإثبات وجودها وإنا

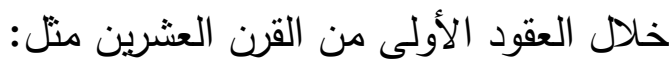

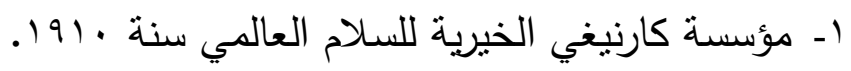

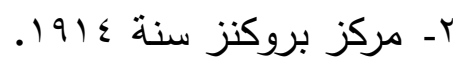

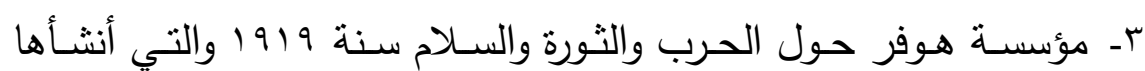
الرئيس الأمريكي هربرت هوفر هوفر (').

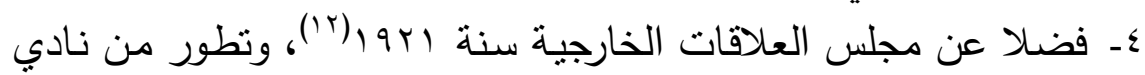

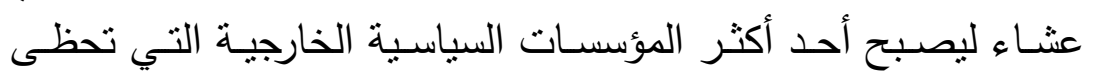

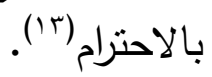

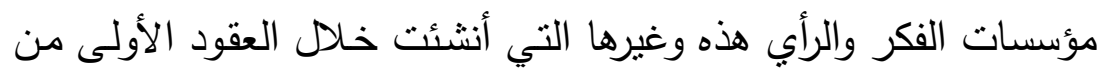

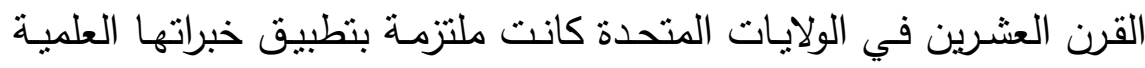

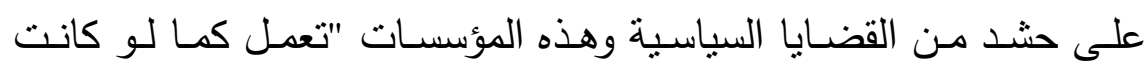

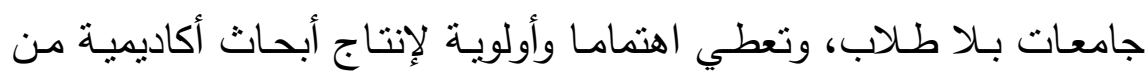
نوعية عالية"(؛ (1). 


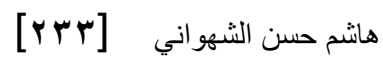

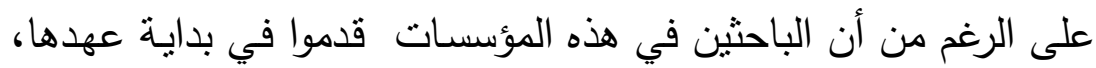

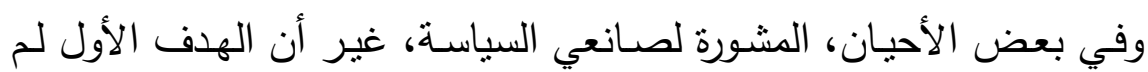

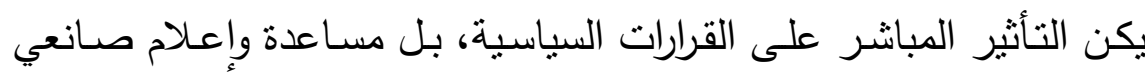

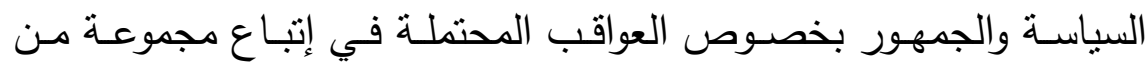

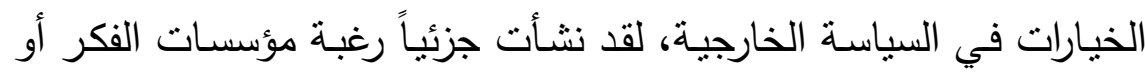

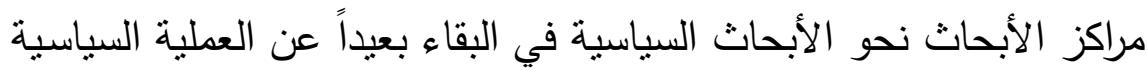

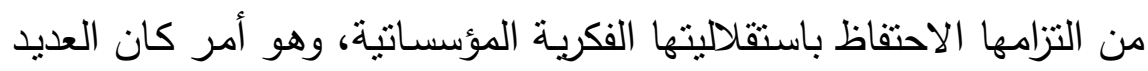

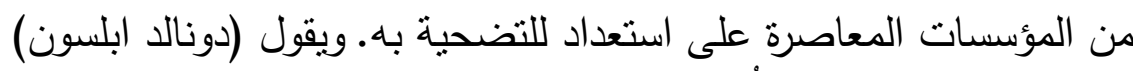
DONALD ABLSON

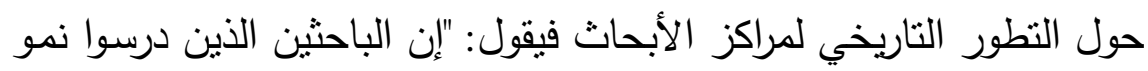

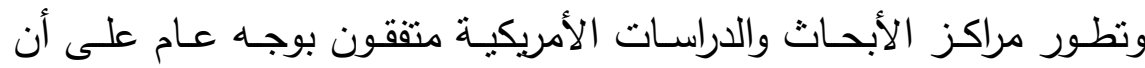

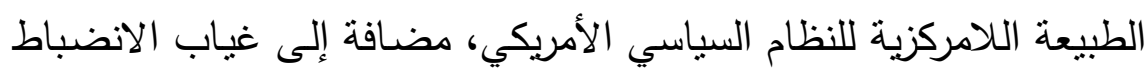

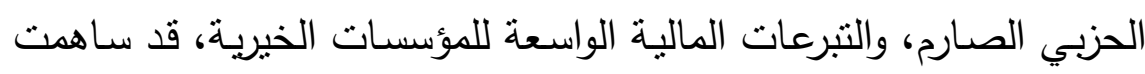

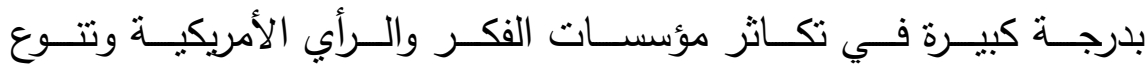
اهتماماتها" (10).

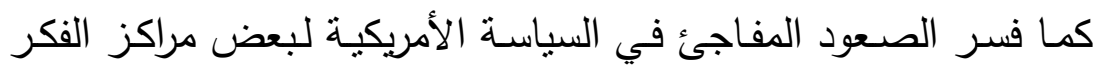

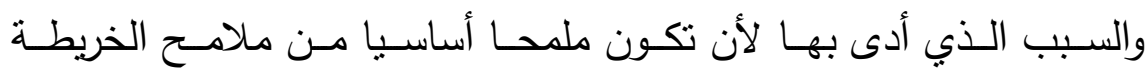

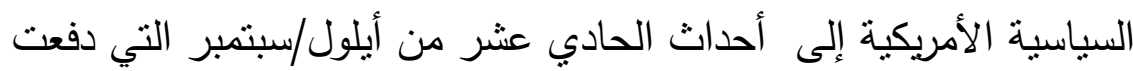

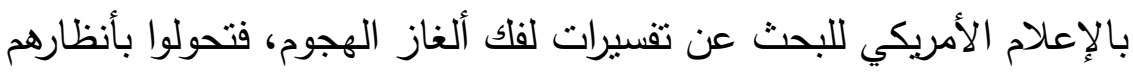

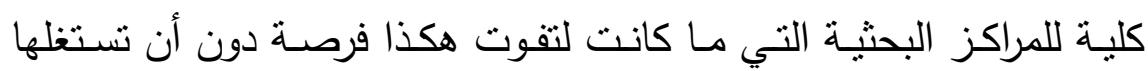

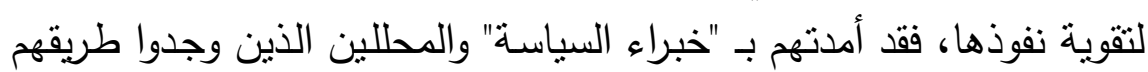

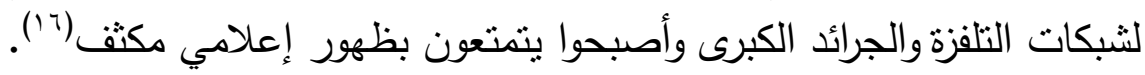

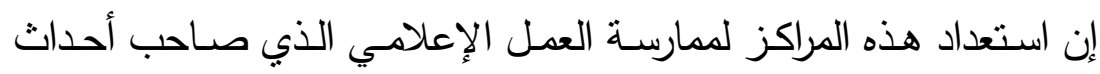

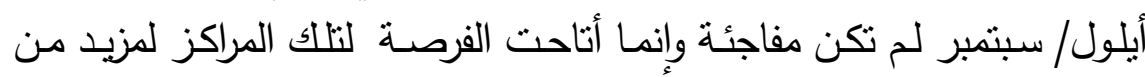

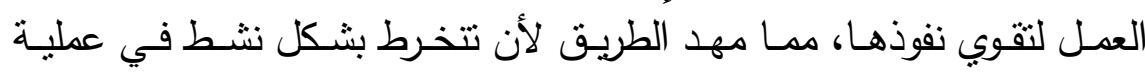


GEMS سناعة القرار السياسي، وفي هذا السياق يقول (جيمس ماكغان)

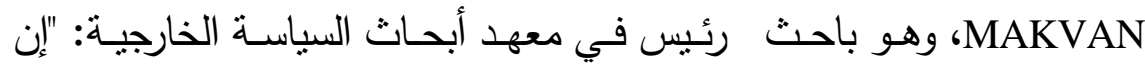

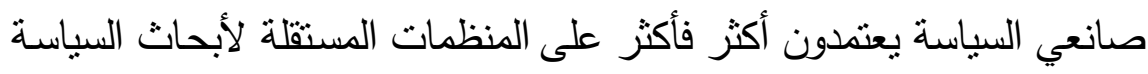
العامة والتي تعرف بمؤسسات الفكر والرأي من أجل توفير معلومات وتحليلات

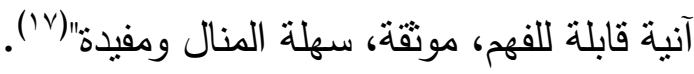

\section{التمويل}

تتميز المؤسسات الفكرية الأمريكية بميزانياتها الضخمة مقارنـة بالمراكز الفكرية في باقي أنحاء العالم. ويذكر أحد السياسبين السابقين (دولاريكيين)

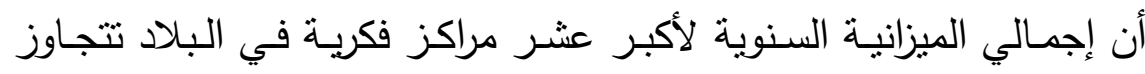

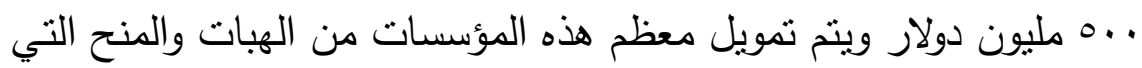

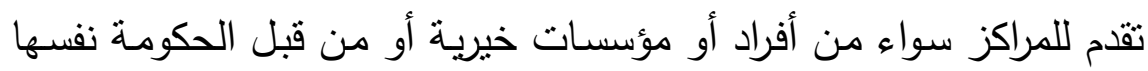

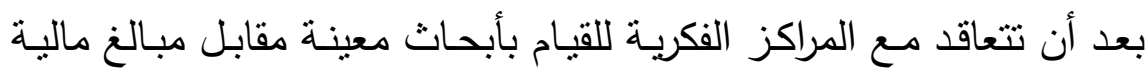

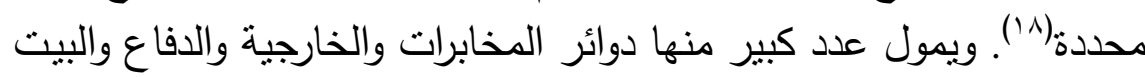
الأبـيض والثـركات القابضـة، كالمـال والسـلاح والـفط والمرتزقـة والإعـلام

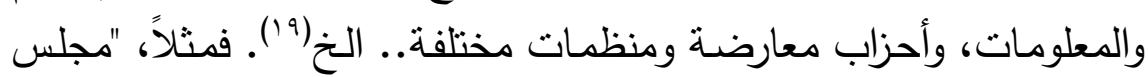

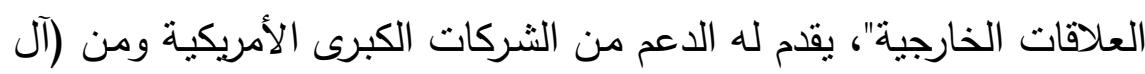

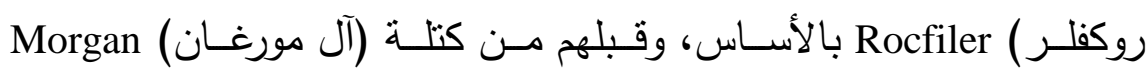

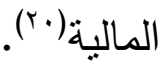
في عام 911 امصل عدد ثلاك المراكز في الولايات المتحدة إلى ألف مركز ، نصفها تقريبا ارتبط بجامعات رسمية والنصف الآخر يعمل كمؤسسات مستقلة.

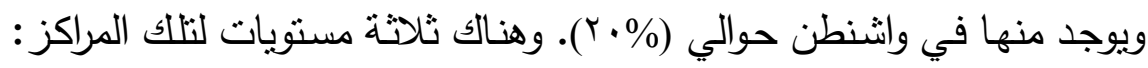

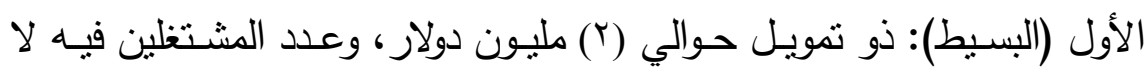

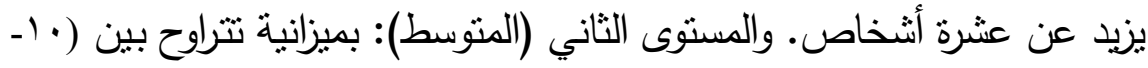
10) مليون دولار سنويا، وعدد العاملين يصل إلى مئة، وهنالك المستوى الثالث: 


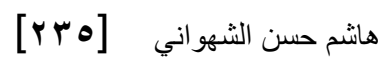

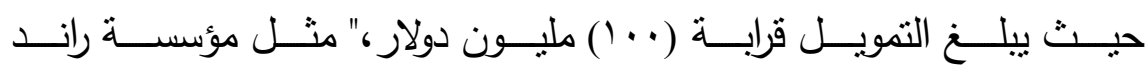

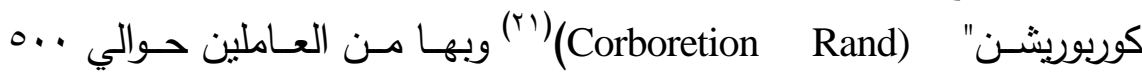

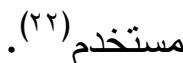

وكمثال أخر لهذه المنظمات يعتمد "مركز الدراسات الإستراتجية العالمية"

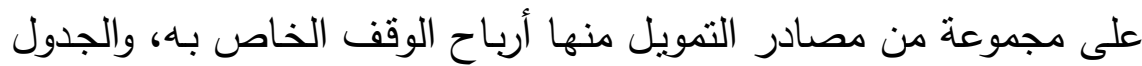

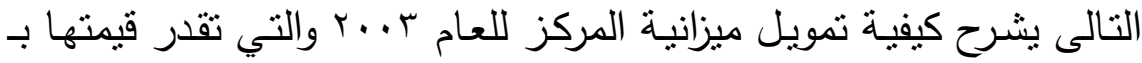

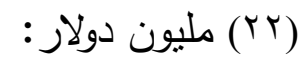

\begin{tabular}{|c|c|}
\hline عدل القيمة من إجمالي الميزانية & مصدر التمويل \\
\hline $37 \%$ & المؤسسات \\
\hline$r \leqslant \%$ & 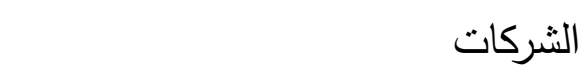 \\
\hline $8 \%$ & التبرعات الشخصية \\
\hline $7 \%$ & الحكومة الأمريكية \\
\hline $6 \%$ & مصادر أخرى وقف المركز \\
\hline $7 \%$ & (بما فيها المبيعات ورسوم الاثتنراكات) \\
\hline
\end{tabular}

مصدر المعلومات: التقرير السنوي لمركز الدراسات الإستراتجية العالمية لسنة ؛... ب.

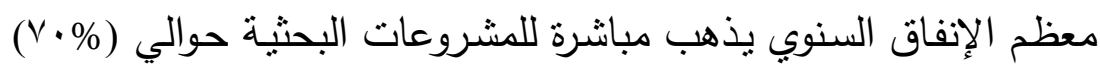

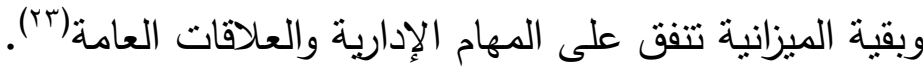

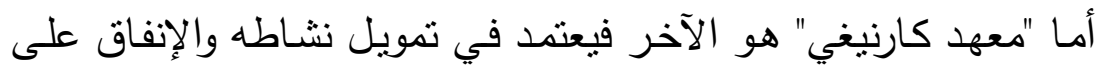

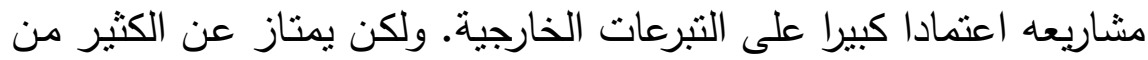

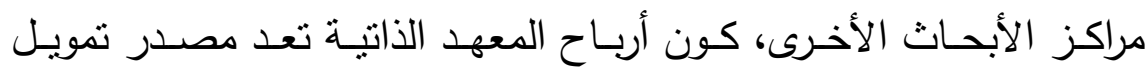


دراسات إقليمية $\wedge$ ( ( )

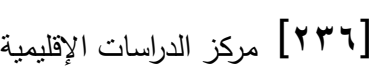

أساسي لتغطية احتياجاته المالية التي وصلت لأكثر من •r مليون دولار

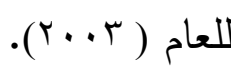

والجدول التالي يوضح مصادر تمويله للعام ؛ ...

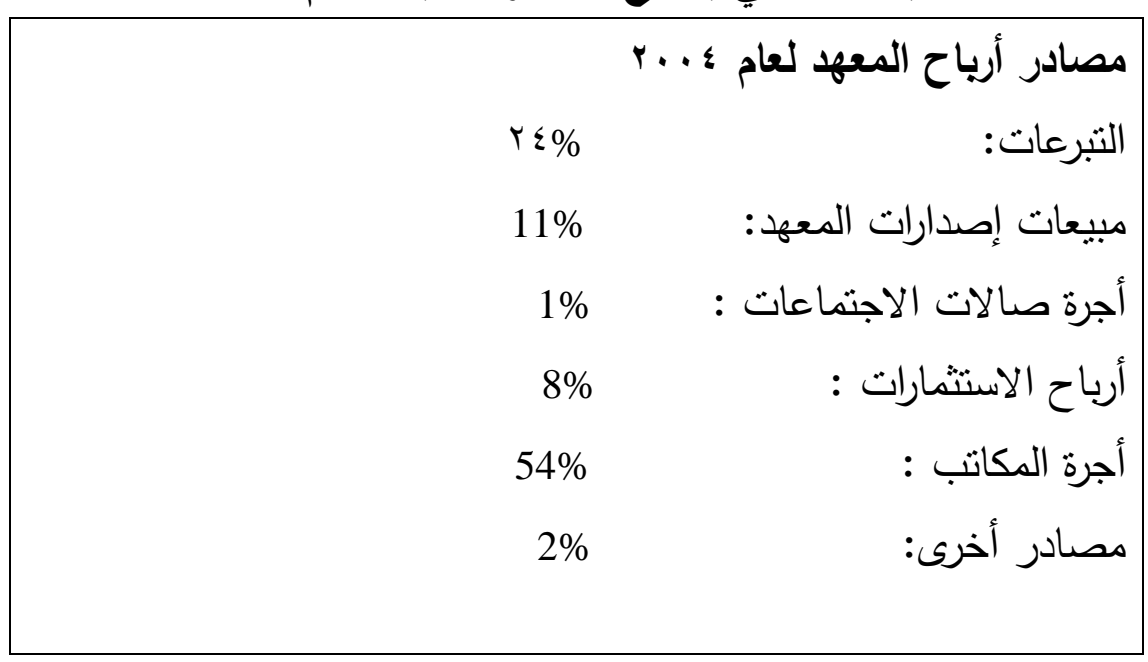

مصدر المعلومات: التقرير السنوي لمعهد كارنغي للسلام الدولي لعام ؛ ...؟.

نلاحـظ مـن الجدول أن المعهد أسـتطاع أن يخفض مـن اعتمـاده على مانى

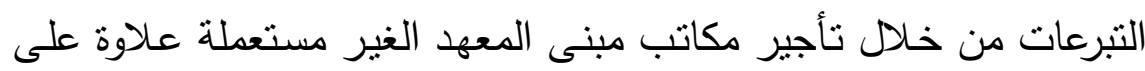

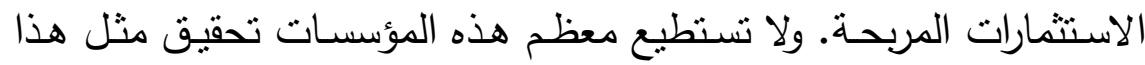

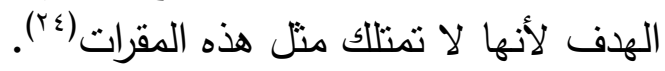

تأثير مراكز الأبحاث في السياسة الخارجية الأمريكية

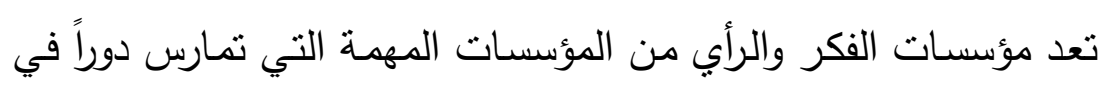

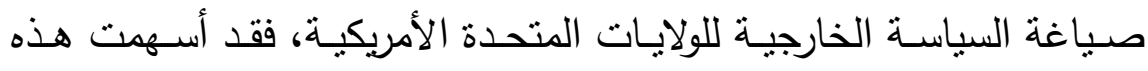
المراكز بشـكل كبيـر في بلـورة الآراء والمبـادئ والمفـاهيم التي أثنرت في لئهي

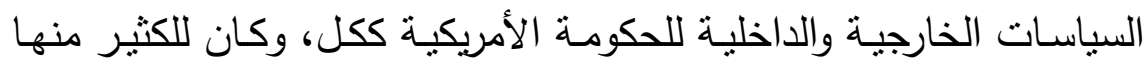




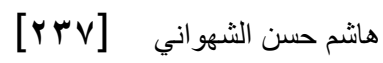

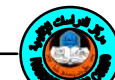

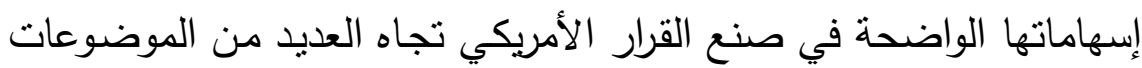

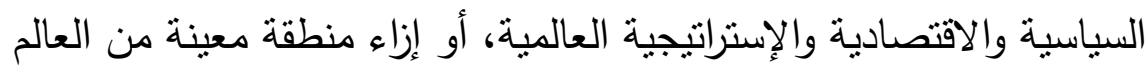

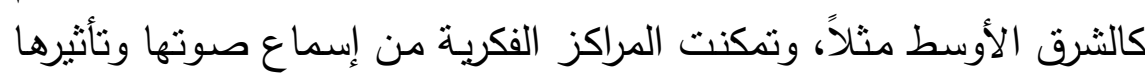

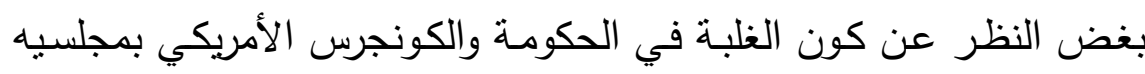

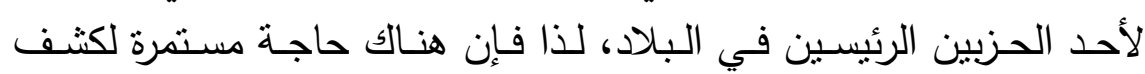

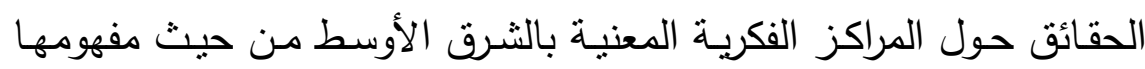

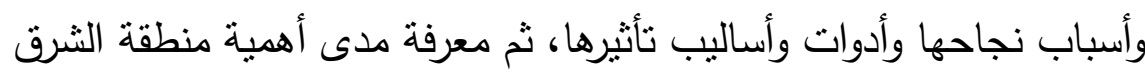

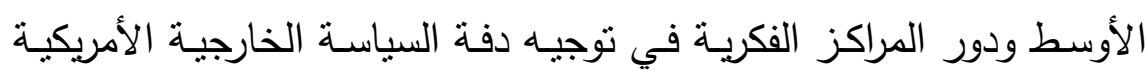

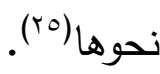

كان لبعض من هذه المراكز فاعلية في التأثير على تصرفات الإدارات

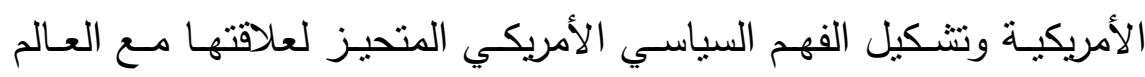

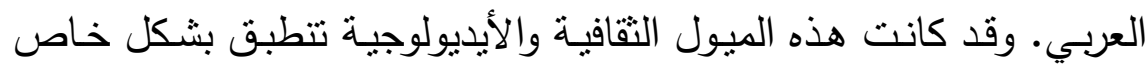
على الصراع العربي - الإسرائيلي (جنان.

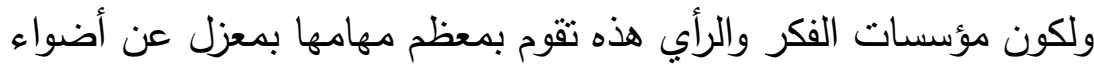

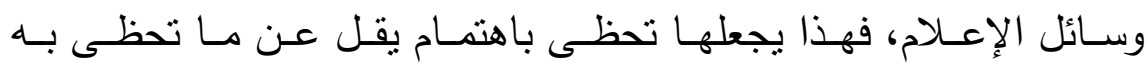

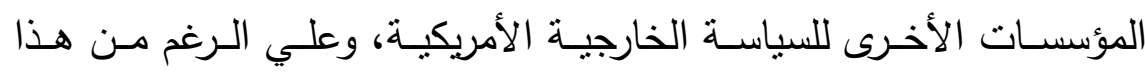

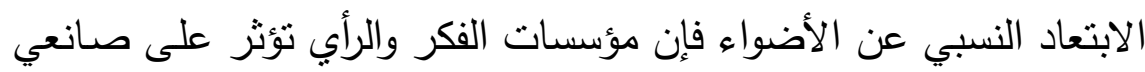

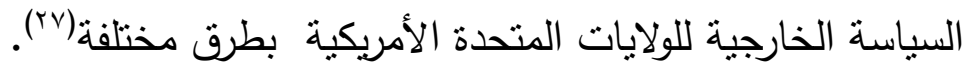

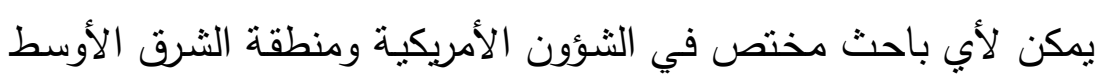

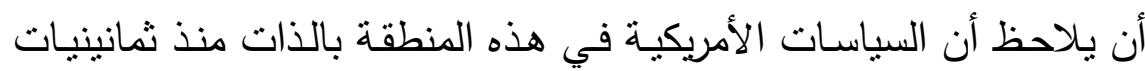

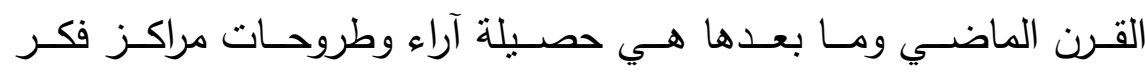

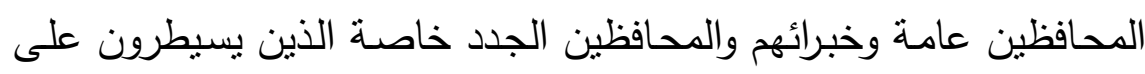

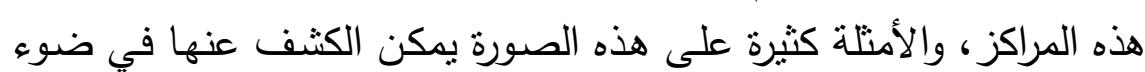

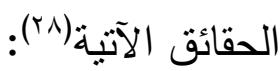


مصطلح "محور الثـر" الذي وضـع كي يصف كوريـا الثمالية والعراق وإيران وسوريا، وهذا الوصف صدر عن أحد الخبراء في أهم معاقل الفكر المحافظ في مدينة نيويورك، وهو معهد مانهاتن، وهو الكندي (ديفيد فروم) DAEVED FROM وكاتب مشارك في دورية المحافظين الجدد (ويكلي ستاندارد).

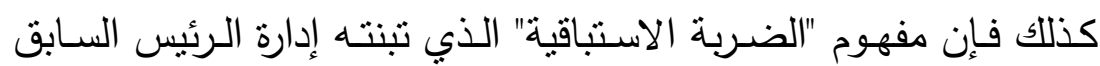

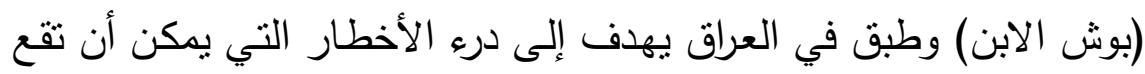
مستقبلا من خـل قيام الولايات المتحدة بعدل انفرادي، وهذا مفهوم طوره

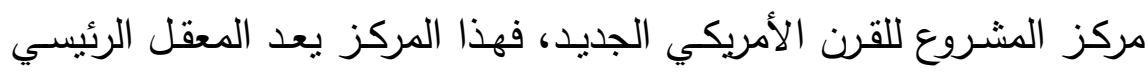
لكبار المحافظين الجدد تم تأسيسه على بد أحد كبار منظريهي، وهو (ويليام كريستول) WILYAM CRISTOL، وكريستول هو الثخص نفسه الذي كان

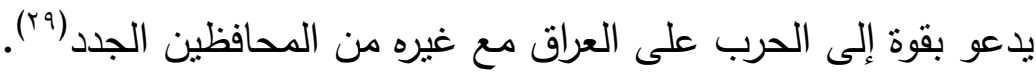
وكان من أهم نتائج هذا الجهد الذي بذله الباحثين والسياسبين أن أصبح

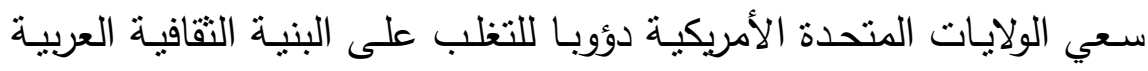

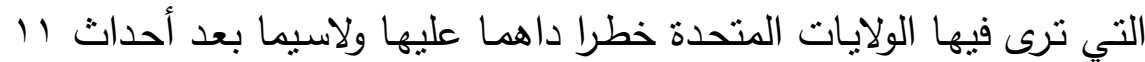
أيلول/سبتمبر، وأصبح لديها اليقين أن المنطقة العربية هي أكثر المناطق

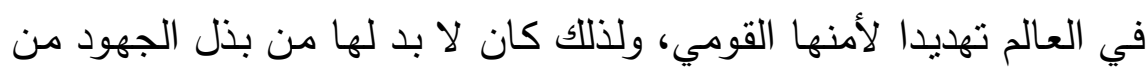
اجل تغيير المحتوى الفكري لثـوب هذه المنطقة من اجل تغيير أحوالها

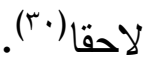

يتتامى دور مراكز الأبحاث والدراسـات في التوجيه والتأثنير في صياغة قرارات السياسة الخارجية للإدارات الأمريكية المتعاقبة تجاه المنطقة العربية،

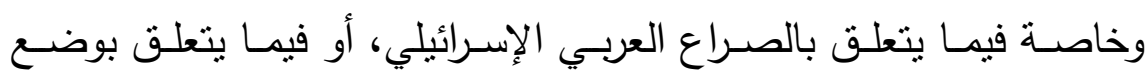
تصورات ومفاهيم وخطط لكيفية التعامل الأمربكي مـع العالم العربي وإدارة

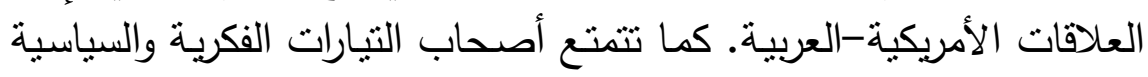
والثقافيـة المعاديـة للعرب داخل هذه المراكز بالتعـاون مـع مجموعـة منتفذة لئه 
داخل الإدارة الأمريكية سبطرة شبه مطلقة على صياغة وصناعة إستراتيجية

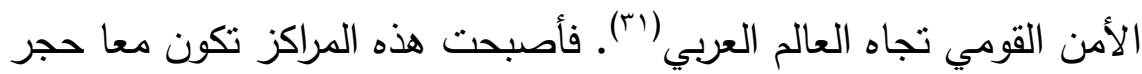

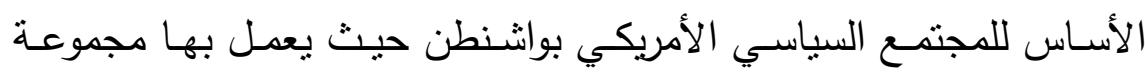

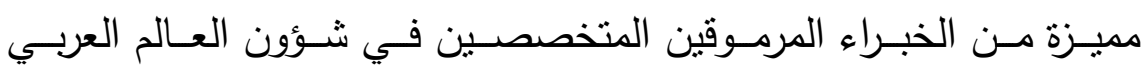
والإسلامي (rT).

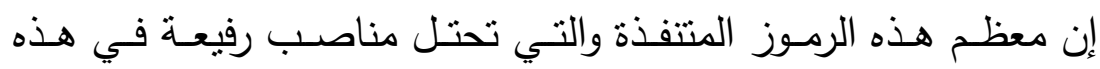

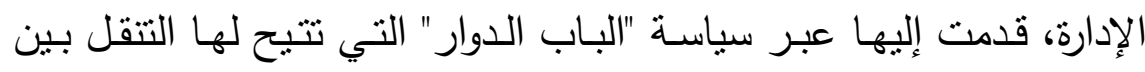

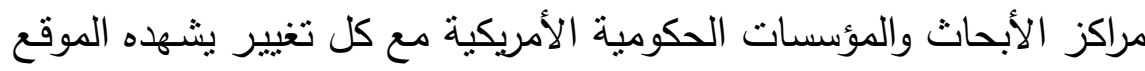

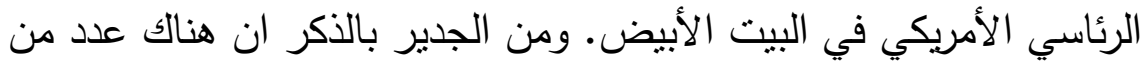
الخبراء المنحدرين من أصل عربي مارسوا أدوارا استثـارية لهذه الإندارات الإني

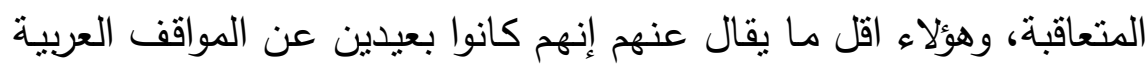

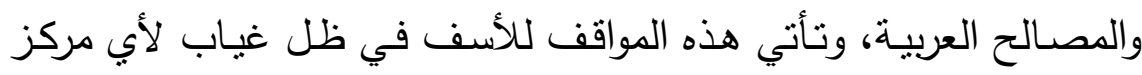

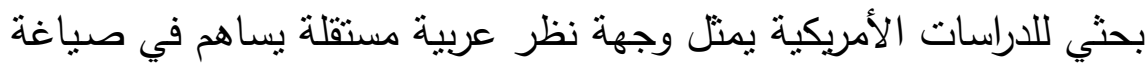

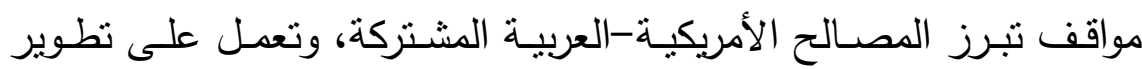

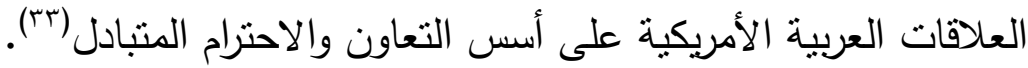

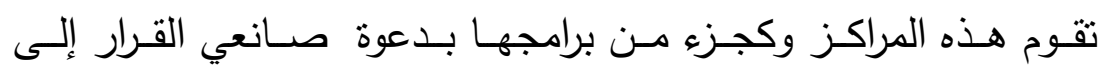
المؤتمرات والملتقيات تركز بعض المراكز الفكرية على هذه هذه الطريقة كوسيلة

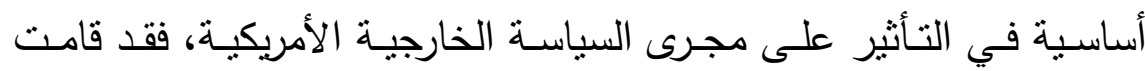

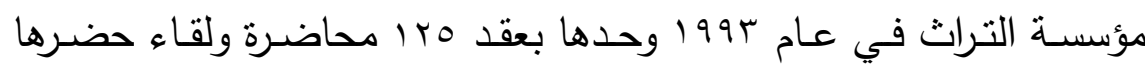

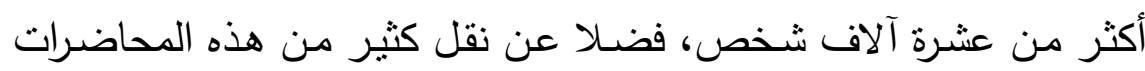

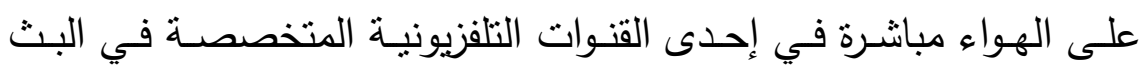

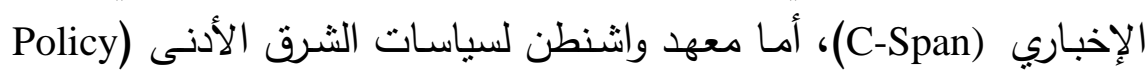

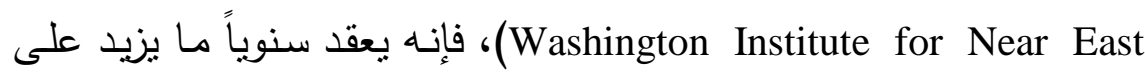
أربعين لقاء ومحاضرة، أي بمعدل يقارب محاضرة أو لقاء أسبوعياً. ويركز المعهد في هذه اللقـاءات على دعـوة المسـؤولين في الإدارة الأمريكيـة، 


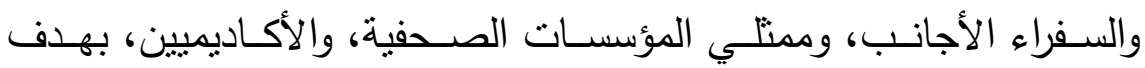
تشكيل قناعات منقاربـة حول قضـايا الثـرق الأوسط، ويقوم المعهد بدعوة

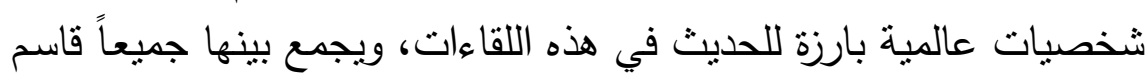
واحد مشترك وهو الاهتمام بمصالح إسرائيل بصورة مباشرة، أو غير مباشرة.

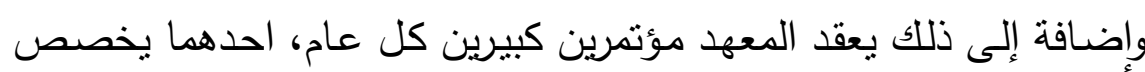

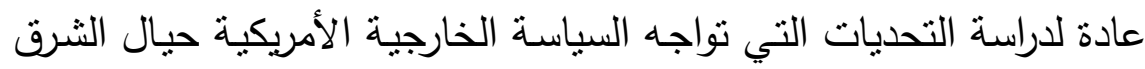

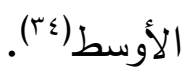

\section{تقسيم مراكز الأبحاث}

ابتداء تصنف المراكز الفكرية في الولايات المتحدة على أنها:

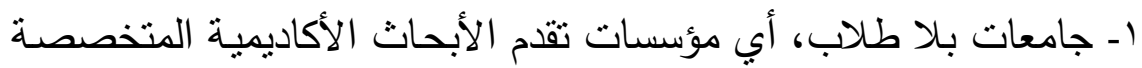

في القضايا السياسية.

r- مؤسسـات استشـارية، وهي المراكـز التي تقدم حلـول عمليـة وخطـوات

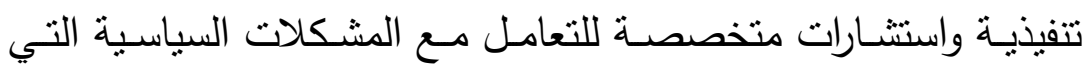

$$
\text { تعرض للإدارة الأمريكية. }
$$

r- مراكز ضـغط سياسـية، وهي المراكز الفكربـة التي تسـتخدم الدراسـات والبحوث والوسائل الأخرى كطرق ضغط مباشـر على الإدارة الأمريكية

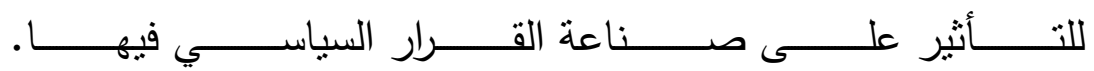
وهي تتقسم فكريـاً وسياسياً إلى مراكز فكريـة يمينيـة محافظـة، ومراكز فكرية معتدلة، ومراكز فكرية يسارية متحررة(ro).

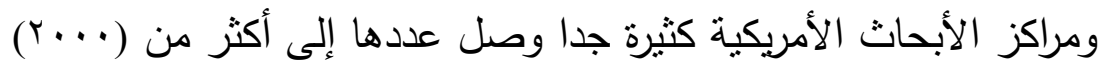

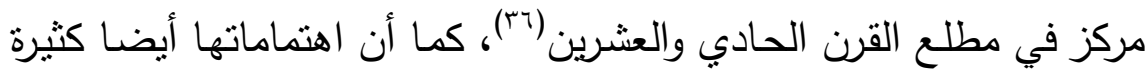

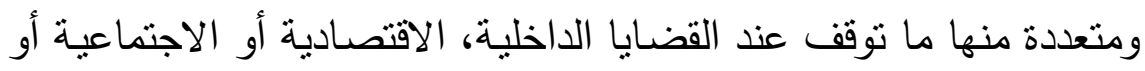

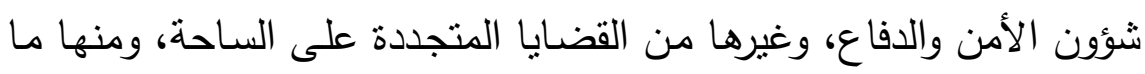

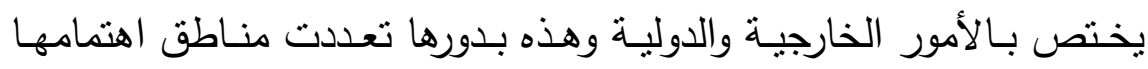


جغرافيا وموضوعيا، والذي يهمنا من أمر تلك المراكز هو ما يخص المنطقة

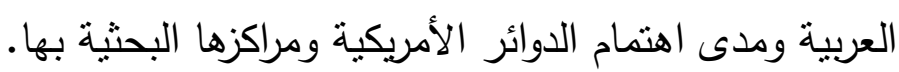

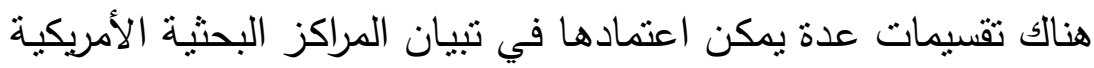

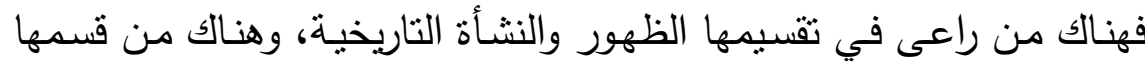
حسب الفئات، وهناك تقسيمات راعت جوانب أخرى، وهنا سنكتفي بتقديم

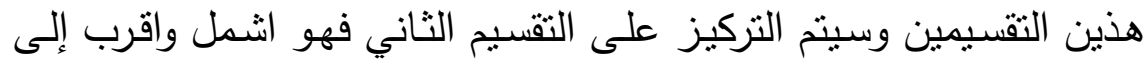

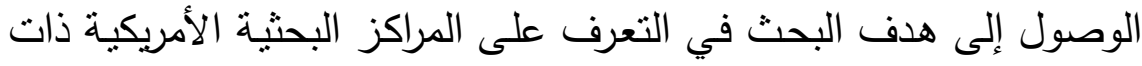
الاهتمام بالقضايا العربية.

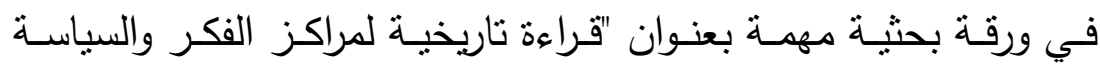

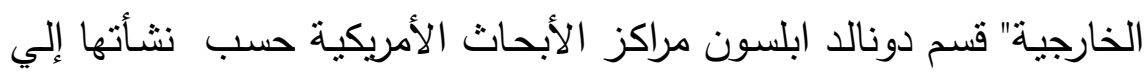

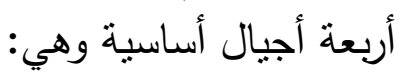

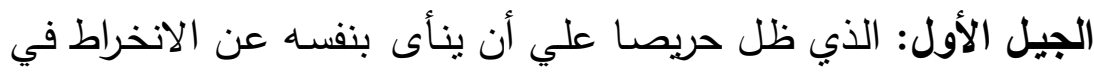

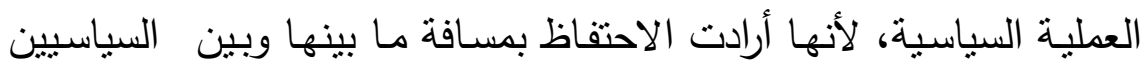

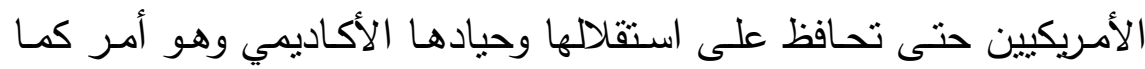

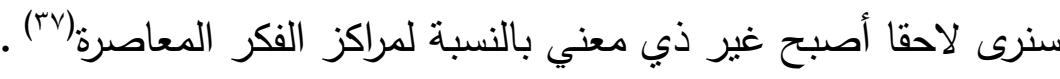

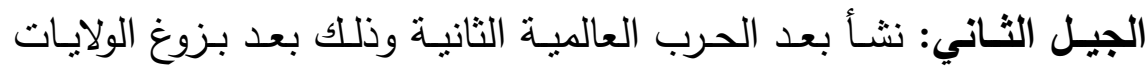

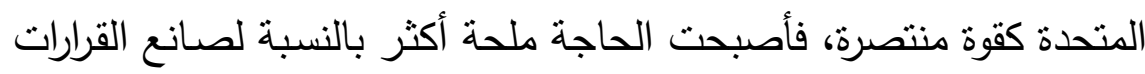

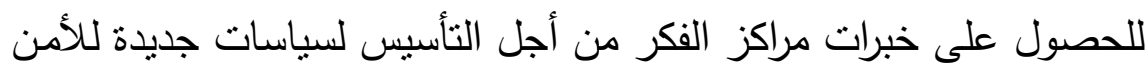

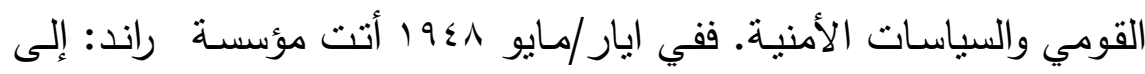

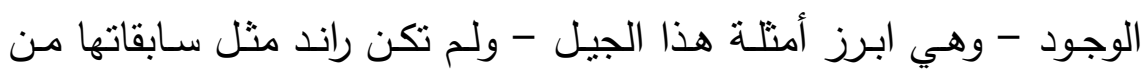

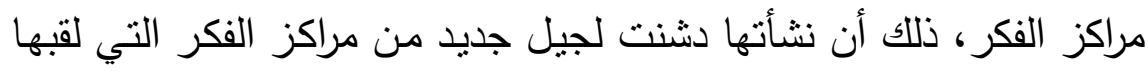

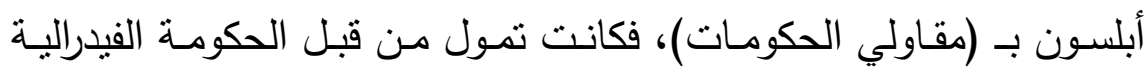

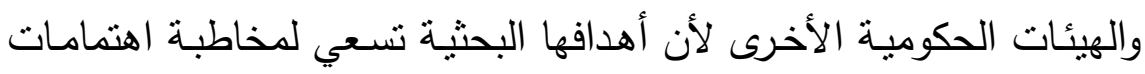

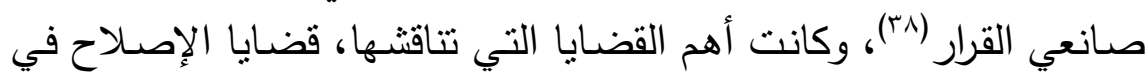

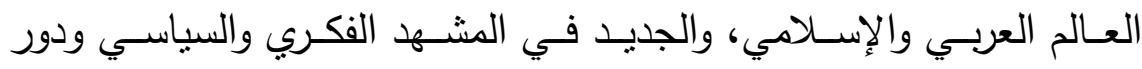


الحركات الوطنية والحركات الإسلامية وتأثيرها في منظومة العمل السياسي العاسي

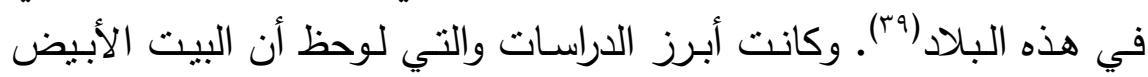

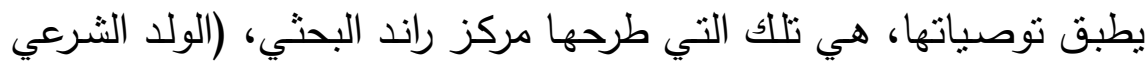

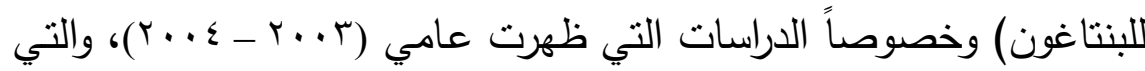

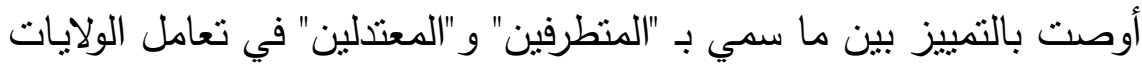

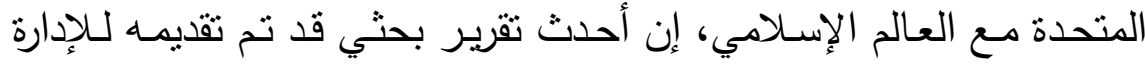

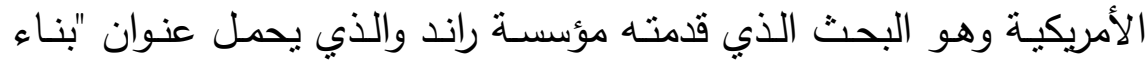

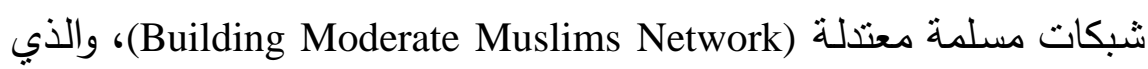

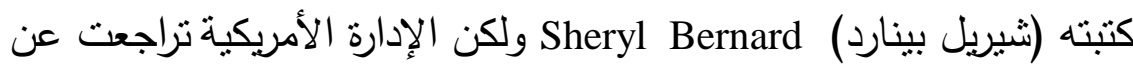
هذه الإستراتيجية استجابة لضغوط عدانيل الضيدة منها:

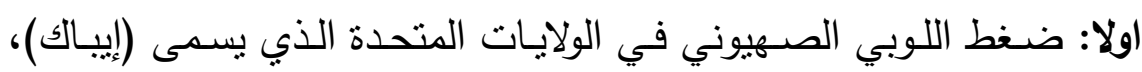

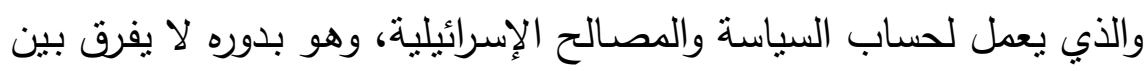

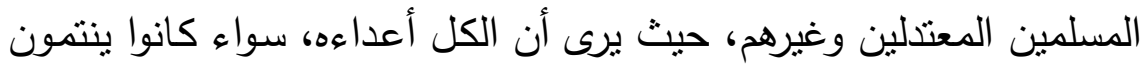

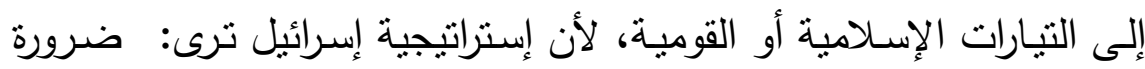

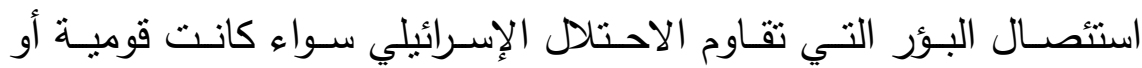

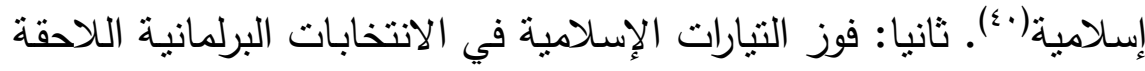

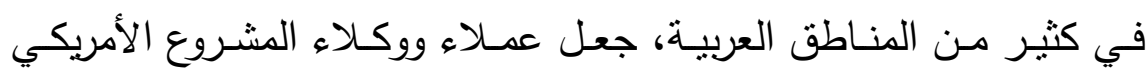

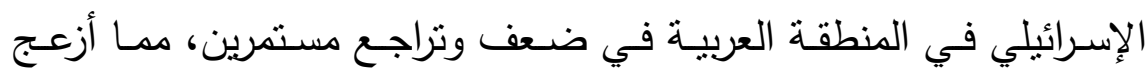
الحكومة الإسرائيلية وبعض النظم العربية، الأمر الذي اقنع الإدئدارة الأمريكية

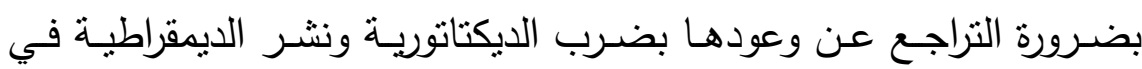

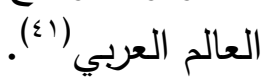

يأخذ المراقبون على راند مآخذ عدة منها نزعنها العسكرية القوية، ووقوفها

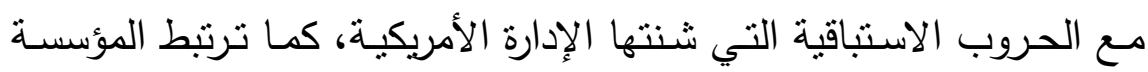

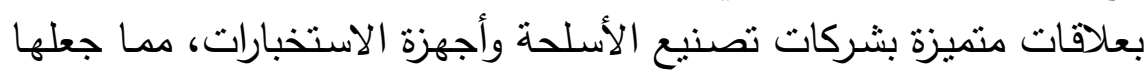
هدفا للكثير من نظريات المؤامرة حتى داخل البلاد. إلا أن منتقدي المؤسسة الهـات 


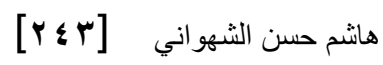

لم يتمكنوا من الحصول على أية ملفات أو وثائق تتضمن أدلة قطعية تثبت

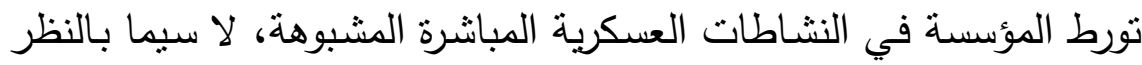

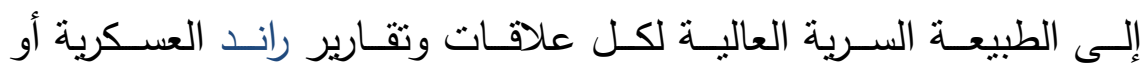
الاستخباراتية(זr).

أما الجيل الثالث: فأهم ما يميزه أنه علي العكس من الجيل الأول الذي الذي لم ينخرط في أية أنشطة سياسية، فإن مراكز الفكر المنتمية لهذا الجيل مثل التيل

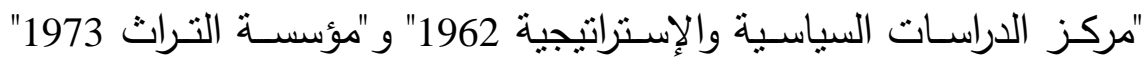

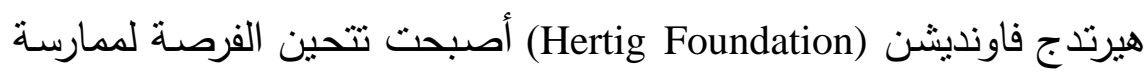
نفوذ على اتجاه ومحتوى السياسة الخارجية الأمريكية. ومع تزايد عدد مراكز

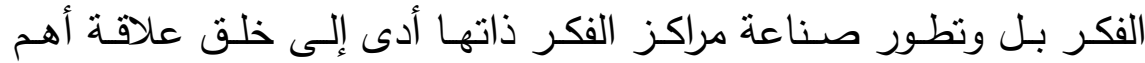

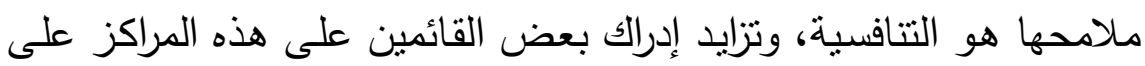

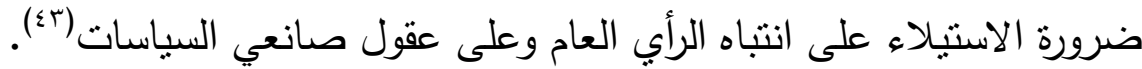

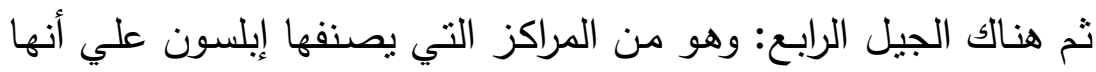

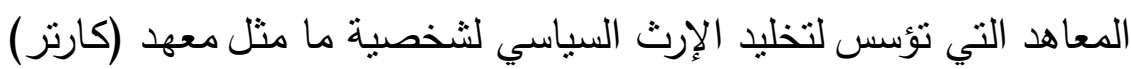

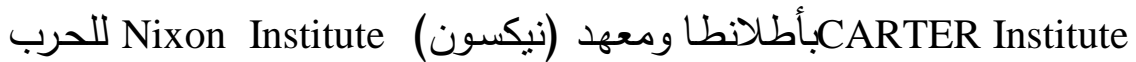
والسلام بواشنطن ومعهر (جيمس بيكر) Gems Baker Institute

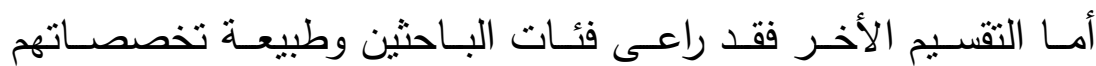
واهتمامات مراكزهم ومن خلال ذللك تم التركيز على اولئك الذين كانت لهم الته

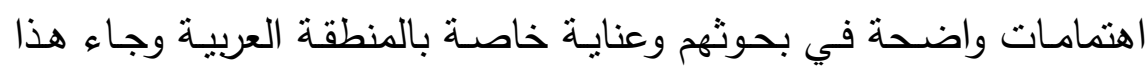

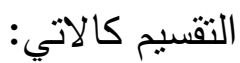
أ- الفئة الأولىى

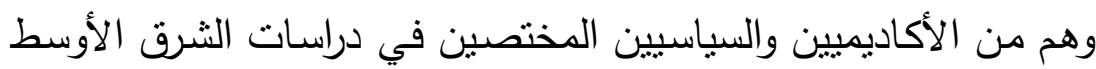
والعلاقات الخارجية في الجامعات الأمريكية. وارتبطت أسماء هولاء الباءئن الباحثين

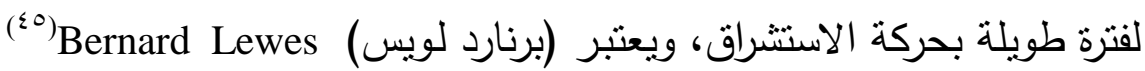




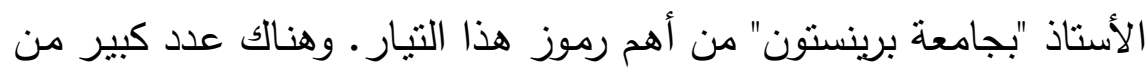

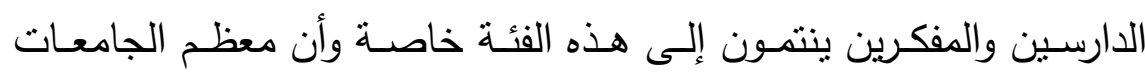

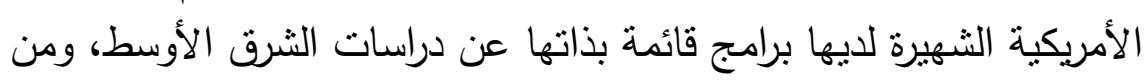

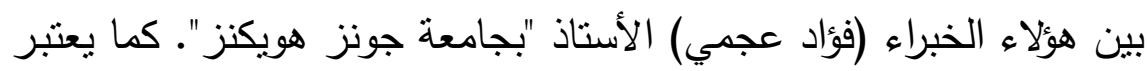

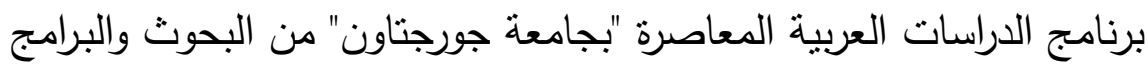

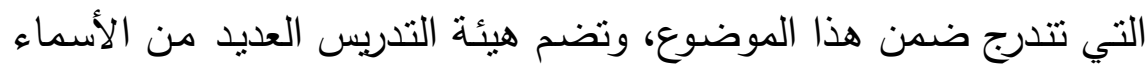

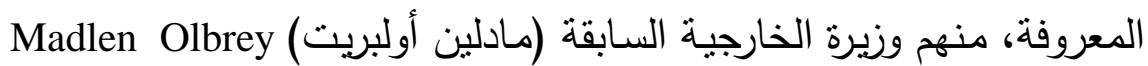

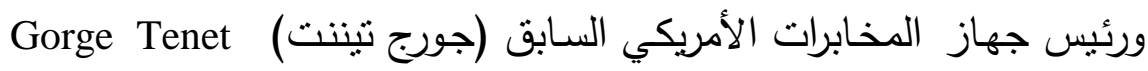
Goose Maria Aznar ورئيس وزراء أسبانيا السابق (خوزيه ماريا أزنار) إلى جانب أسماء أخرى كثثرة:(

\section{ب- الفئة الثانية}

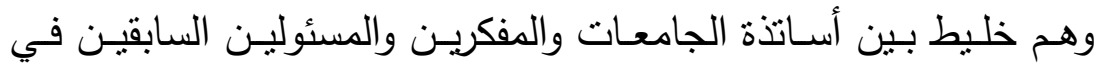

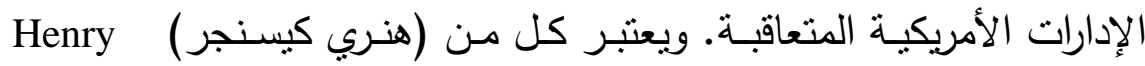

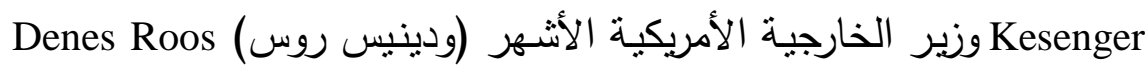

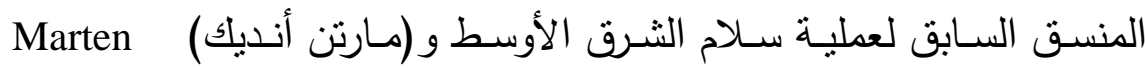
Andek

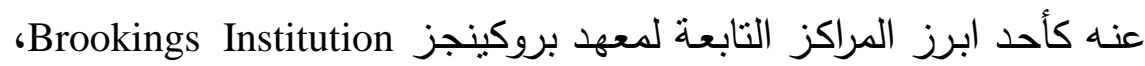

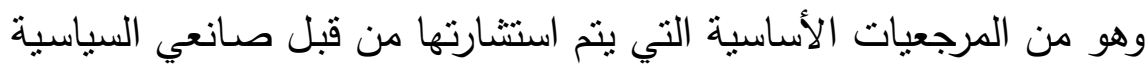

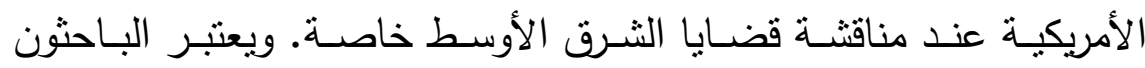

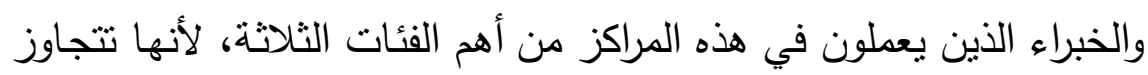

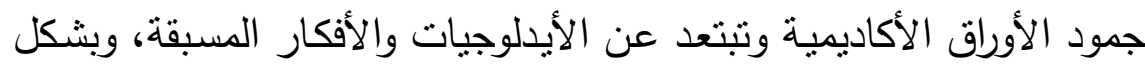

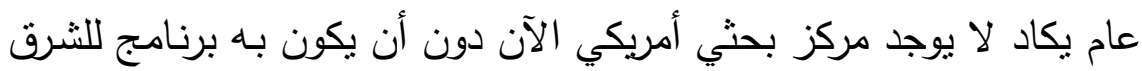

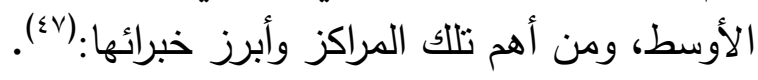




\section{1 - معهt بروكينجز: (Brookings Institution)}

الذي يعرف عن نفسه بأنها منظمـة غير ربحية وغير حزبية. وعلمائها يمتلون وجهات نظر متتوعة ومقرها في واشنطن العاصمة، يقوم بإجراء

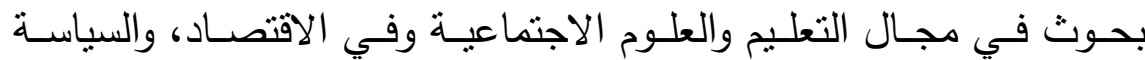

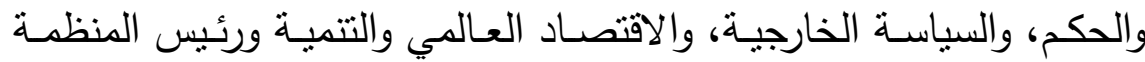
(ستروب تالبوت) Strobe Talbot)

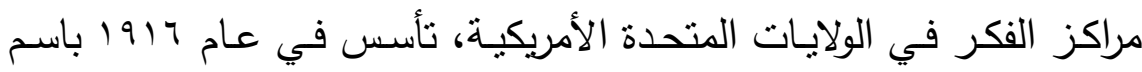

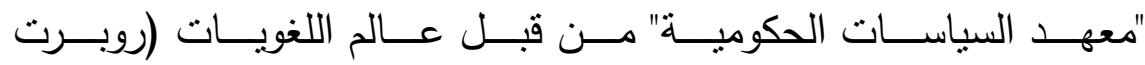

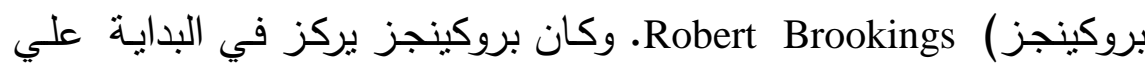

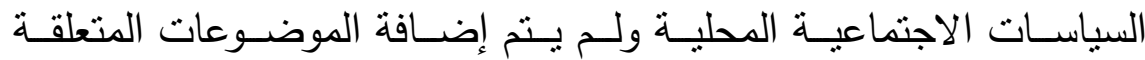

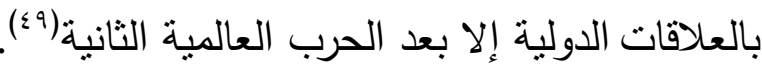
يعد السيناتور (جوزيف بايدن) Josef Bayden ارفع مسؤول ديمقراطي

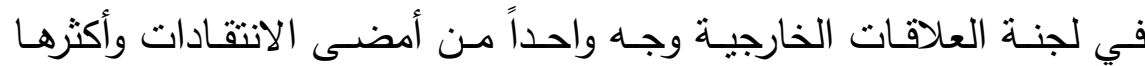

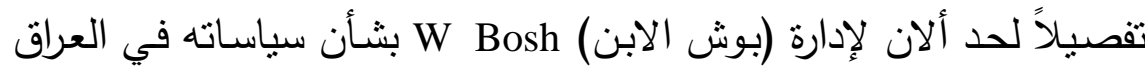

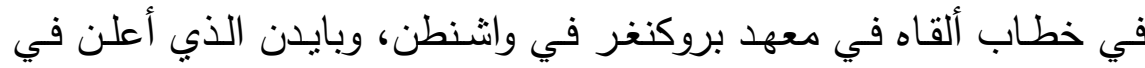

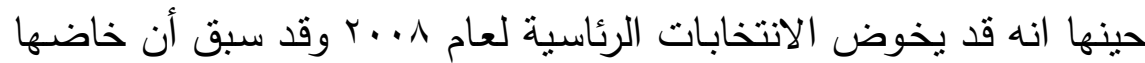

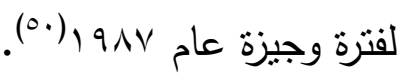

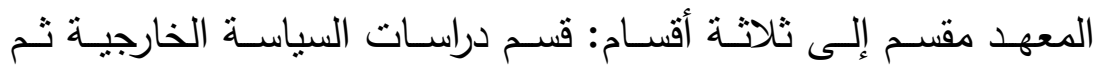
الدراسات الاقتصادية والدراسات الحكومية، والهيكل التتظيمي للمعهد يضم

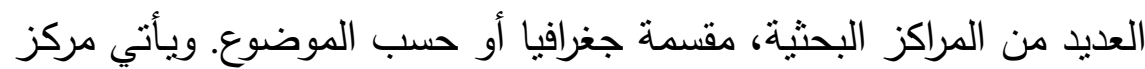

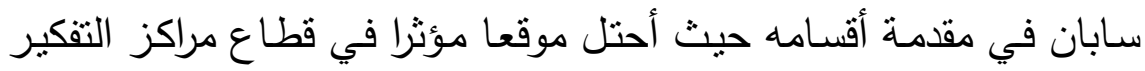

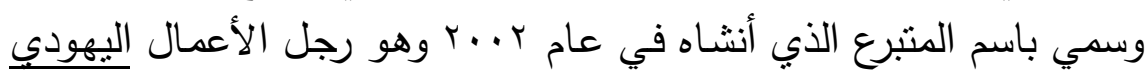

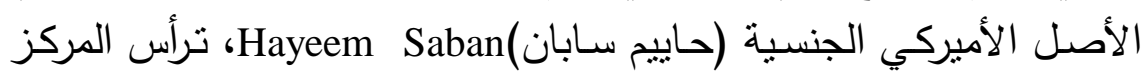

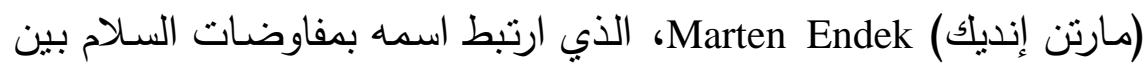

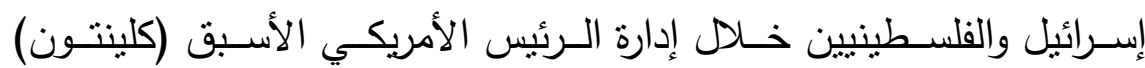


Kenneth Bolak Clinton

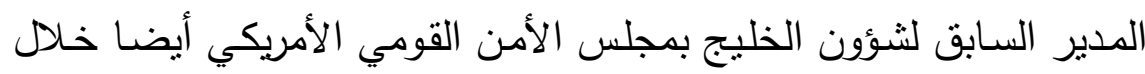

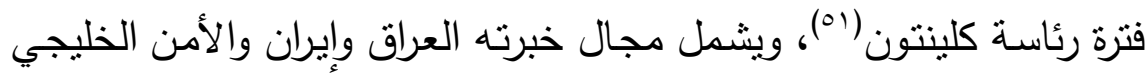
والثؤون العسكرية بالعالم العربي. وبولاك هو مؤلف لثلاثة كتب شهيرة وهي ولئي "المعضلة الفارسية: الصراع بين إيران وأمريكا"، و "العاصفة الخطيرة: لماذاذ

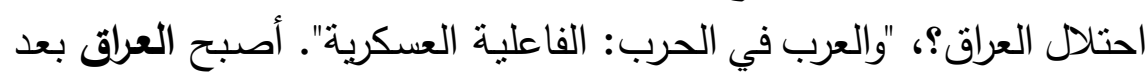

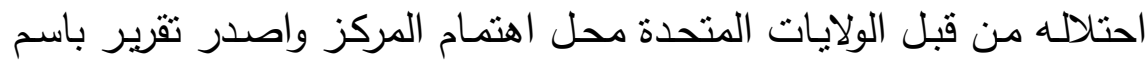
"دليل العراق" وهو تقرير عن الأحوال الداخلية بالعراق متمنلة في مؤشرات الهات

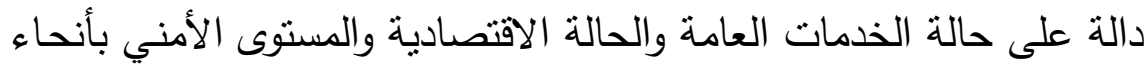

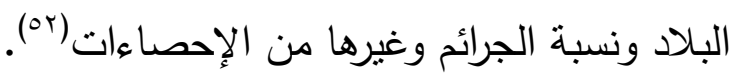
كان للأفكار التي صدرت عن بروكينجز دور كبير وأساسي في التعبئة من أجل تبني سياسة العقوبات على ما يعرف بالدول (المارقة)، وكان وراء

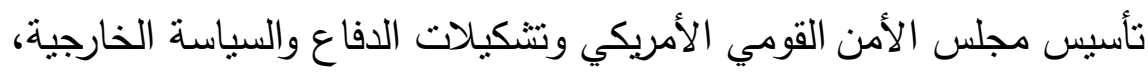
ومنذ أحداث الحادي عشر من ايلول/سبتمبر أصبحت الأبحاث أكثر تركيزا

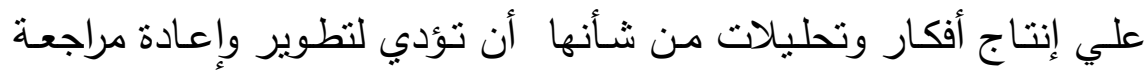

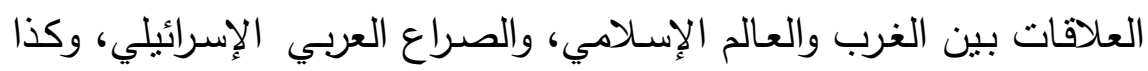

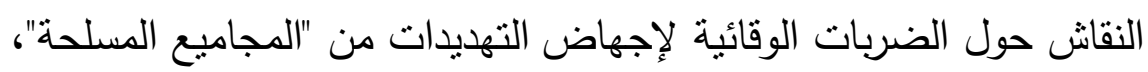

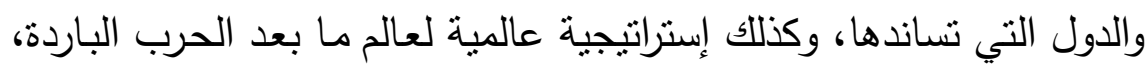

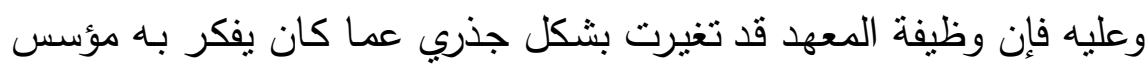

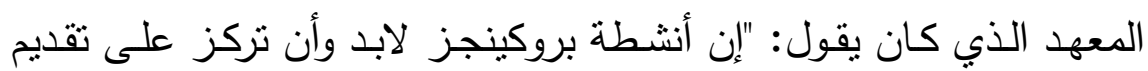

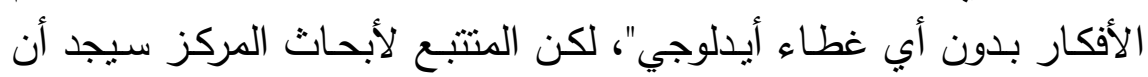

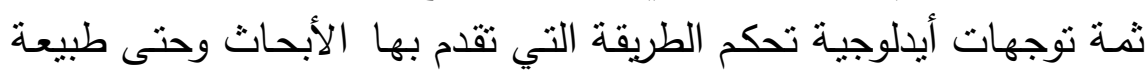
الموضوعات التي يتم اختيارها والأفكار التي تقدم لصانعي السياسات والرأي 


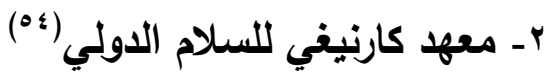

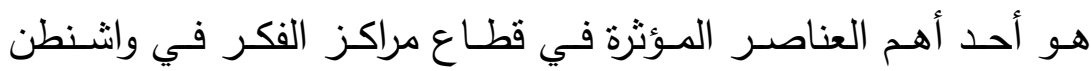

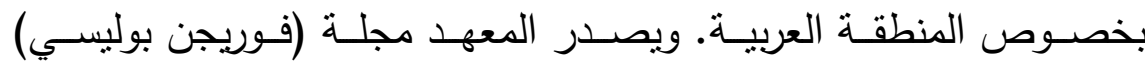
Foreign Policy

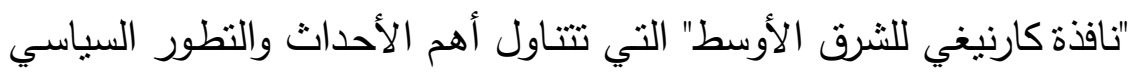

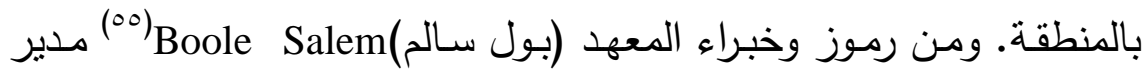

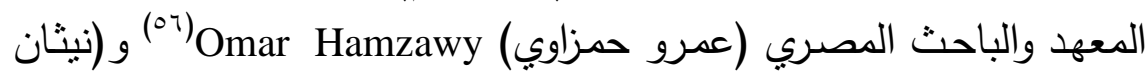

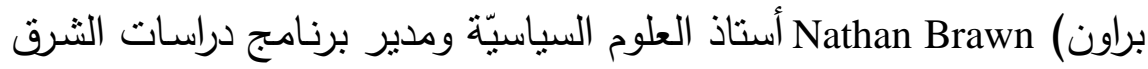

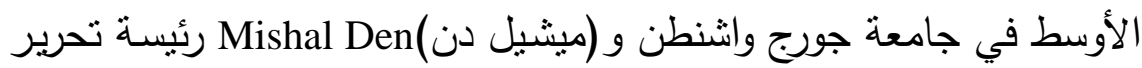

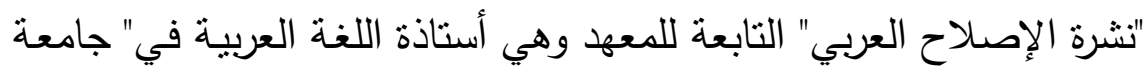

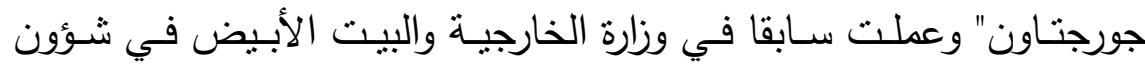

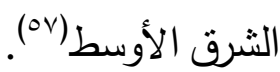

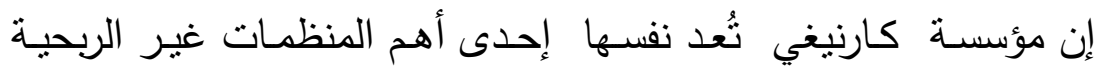

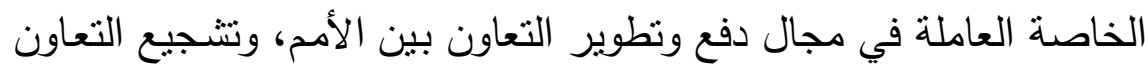

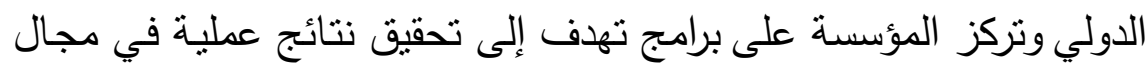

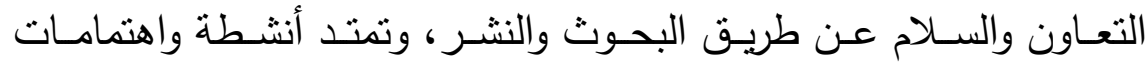

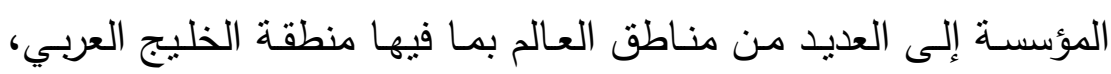

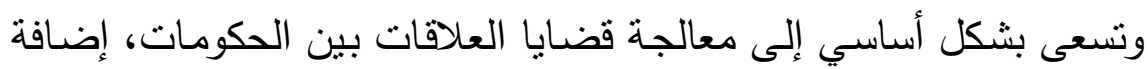

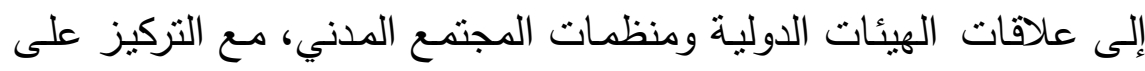
تتبع ودراسة العوامل الاقتصادية والسياسية والتقنية التي تقود عملية التغيير التير التئي العالمي (ن).

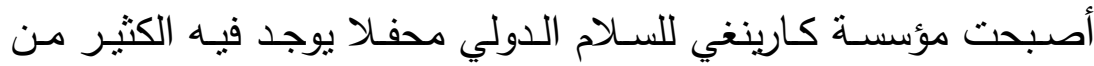

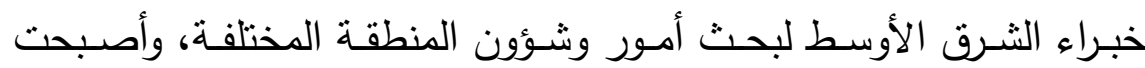

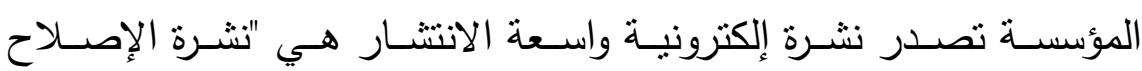
العربي". كما أن مجلس الثؤون الخارجية يعقد الكثير من المؤتمرات وينشر الأنسر 
العديــ مـن الأبحـاث المتصـلة بدبلوماسية الولايـات المتحدة وقضـايا الـفط

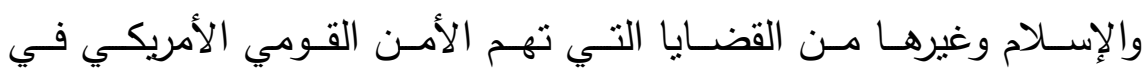

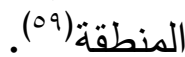

عمدت مؤسسة كارينغي إلى إنشاء مركز بحوث في الشرق الأوسط في

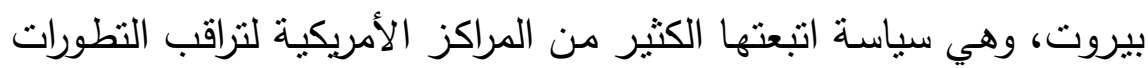

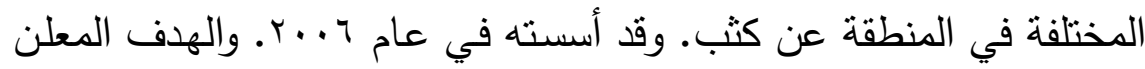
لانشـاءه هو التحديات التي تواجه التتمية السياسية والاقتصـادية والإصـلاح في المنطقة العربية. وهو يجمع بين كبار الباحثين من المنطقة للعمل على لـى لاعلى

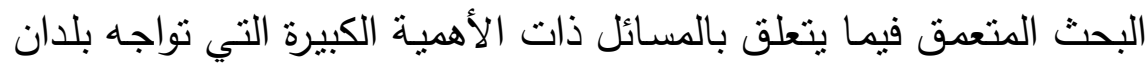

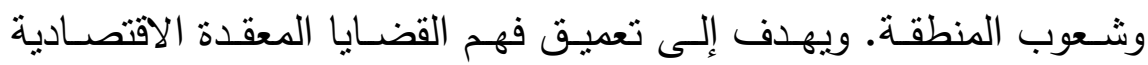
والأمنيـة التي تؤثز على واقع ومستقبل المنطقة وانعكاسـها على المصـالح

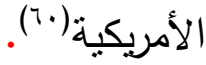

\section{r- معهد أمريكان إنتريرايز}

\section{(Enterprise Institute for Public Policy Research)}

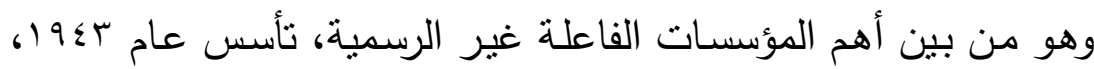

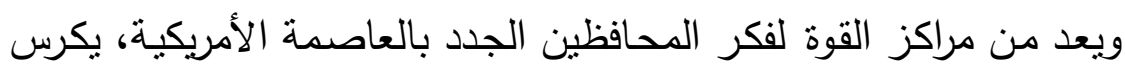

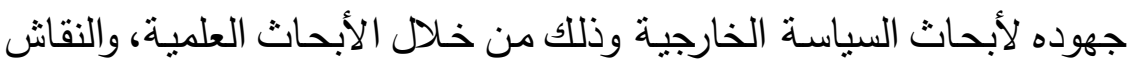
المفتوح، وإصدار المطبوعات، يدير المعهد مجلس أمناء يتألف من ودن 24

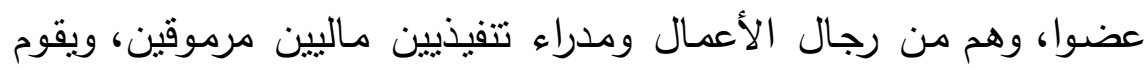
بمراجعة برامج الأبحاث والتعبينات لديه مجلس من المستشارين الأكاديمبين ومدين

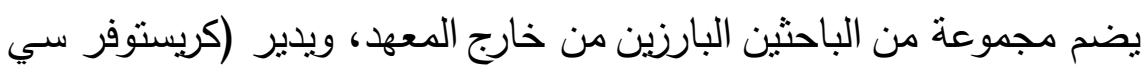
ديموث) Crestover Demoth عمليات المعهد اليومية يتلقى الدعم المالي بالدرجة الأولى من المنح والمساهمات التي تقدمها المؤسسات الوقفية، 


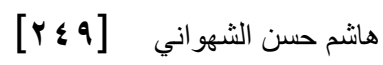

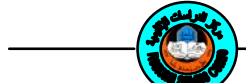

والثركات، والأفراد، وقد بلغت ميزانيته في سنة ... . س سبعة عشر مليون

دولار (11).

وتثمينـا لجهود المعهد أنتـاد الرئيس الأمريكي الأسبق (رونالد ريغان)

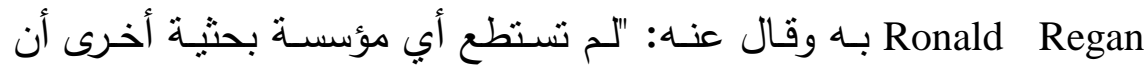

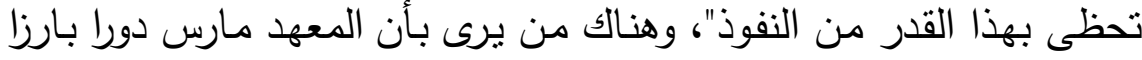

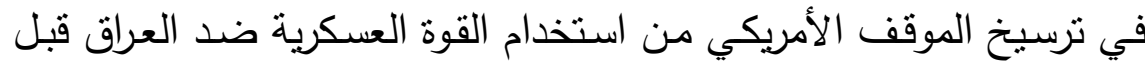

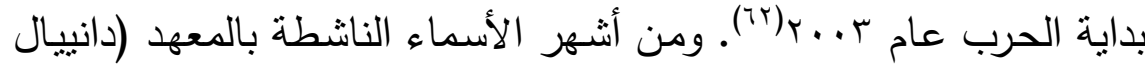

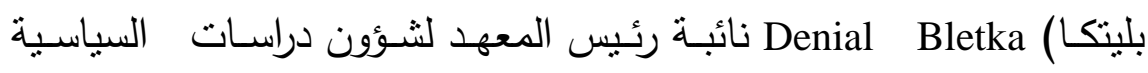

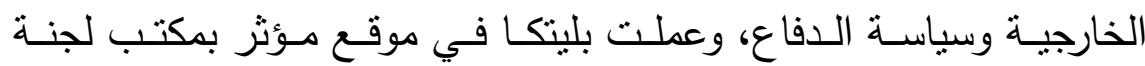

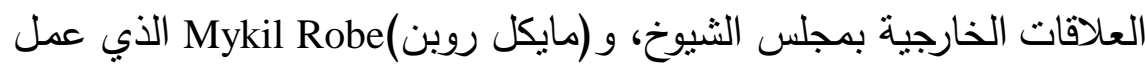

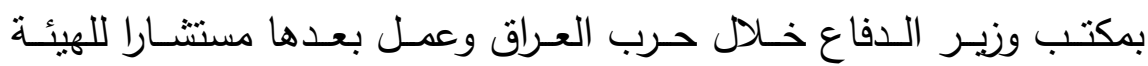

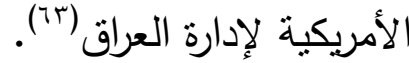

\section{ع - مركز الاراسات الإستراتجية والدولية}

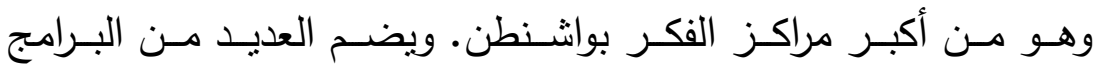

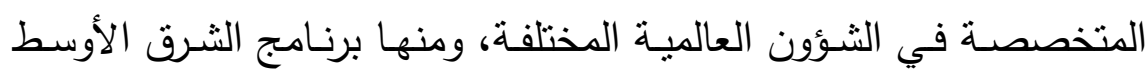

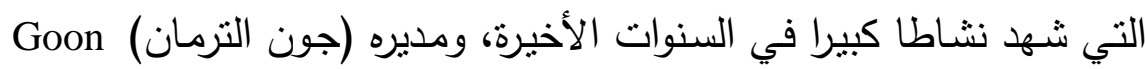
Altraman لمساعد وزير الخارجيـة لنشؤون الثرق الأوسط. وقد درس الترمان بجامعة

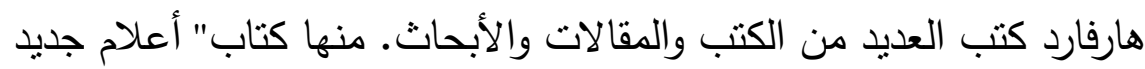

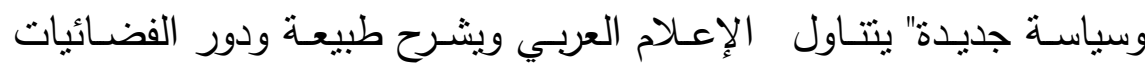

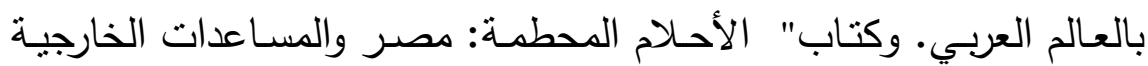

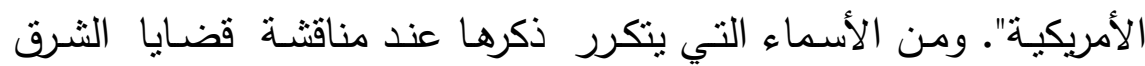

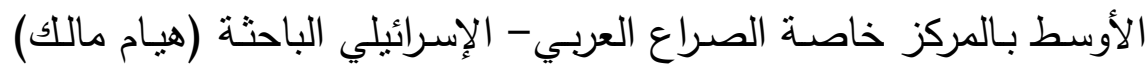
. (१i)Hayam Malik 
ج- الفئة الثالثة

فتتكون من الناشطين السياسيين وأصحاب الأيدلوجيات خاصـة اليمينية أو المناهضـة للعرب والمسلمين، والذين يقدموا بوصفهم خبراء في شؤون

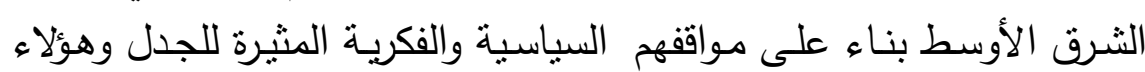
يعملون في معاهد مختلفة منل (70):

1 - معهد المشروع الأمريكي لبحوث السياسات: تأسس في العام بـ19 وقد تطور خلال العقدين الماضيين، فهو أحد أهم مراكز الفكر اليميني و المركز الرئيسي لكبار المحافظين ويضم صقور المحافظين الجدد (باتهان.

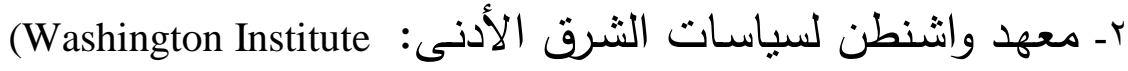
1910 for Near East Policy على الصراع العربي الإسرائيلي، وغالبا ما يتخذ موقفا منحازا ومناصرا لإسـرائيل. عمـل بالمعهد كثيـرا مـن المسؤولين الحكوميين مثنل وزيـرة الخارجية الأمريكية السابقة (مادلين أولبرايت)، والسفير الأمريكي السابق الإني لدى إسرائيل (مارتن أنديك) Marten Endek. كما عمل سابقا (دانييل بـايبس) Daniel Baybs أكثر البـاحثين الأمـريكيين عداء للعـرب

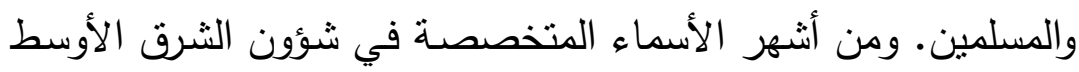
والتي تعمل بالمعهد مديره (روبرت ساتلوف) Robrt Satalof و (دينيس التيس روس) Denes Ros، ويقوم المعهد بإصدار عدد من الدراسات الدورية

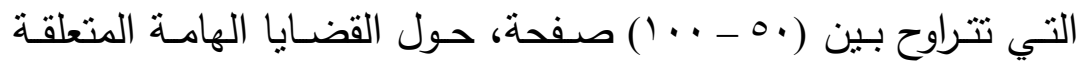
بالثرق الأوسط، وترسل هذه الدراسات إلى أعضاء الكونجرس، وكذلك

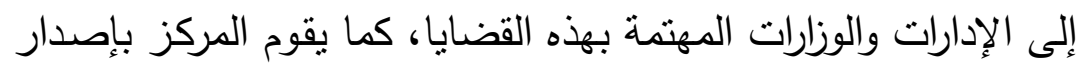

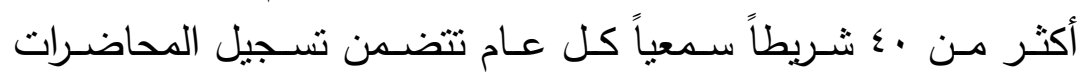

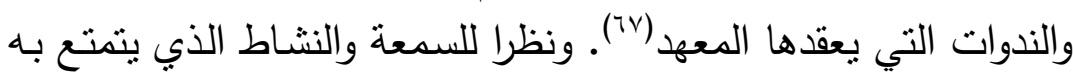

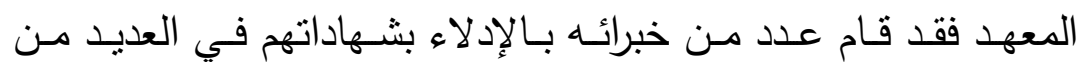




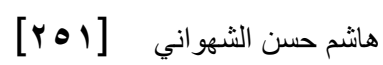

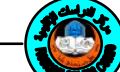

القضـايا المتعلقة بالثـرق الأوسط في السنوات الأخيرة بصفة خبراء

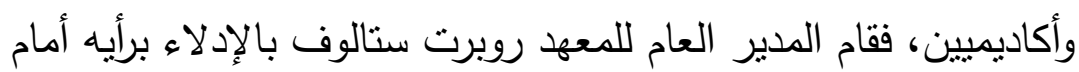

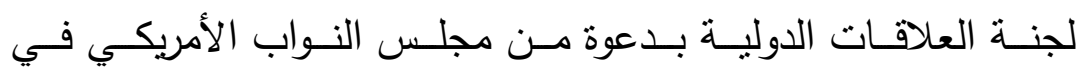

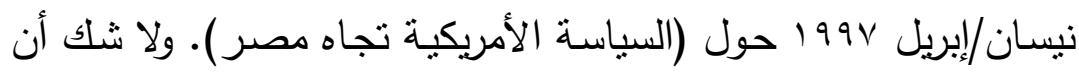

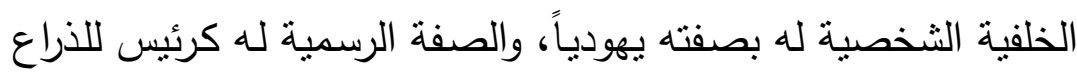

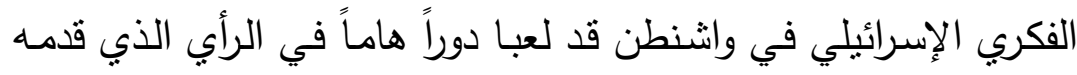

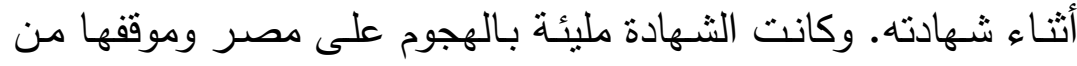

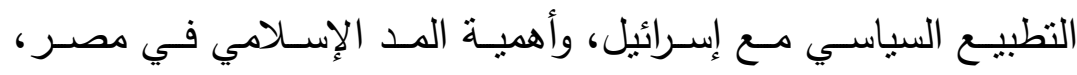

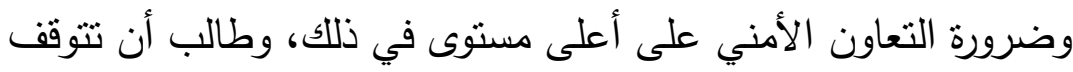

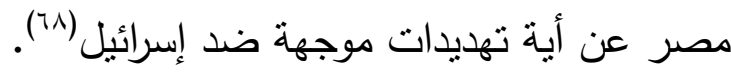

(ستنتاجات

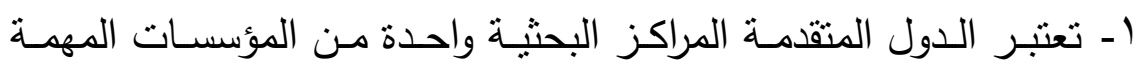

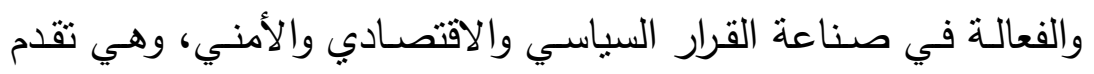

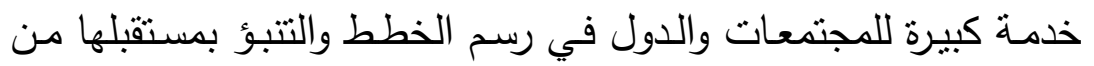

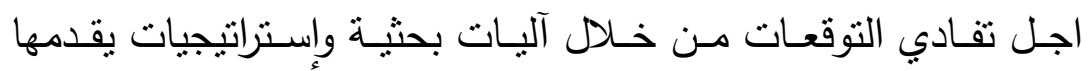

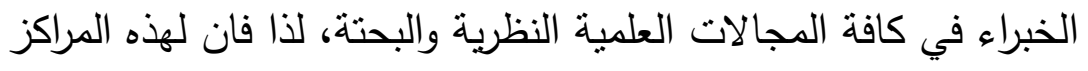

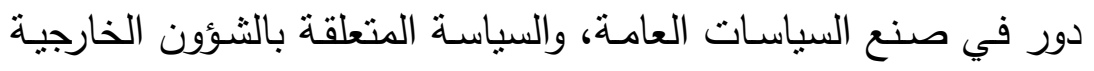
مما اكسبها أهية كبيرة وعلى مراحل زمنية متعددة.

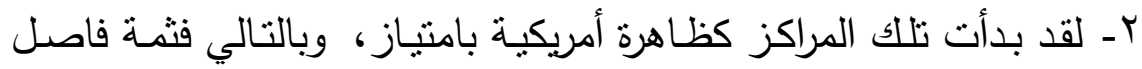

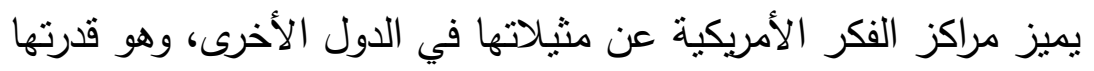

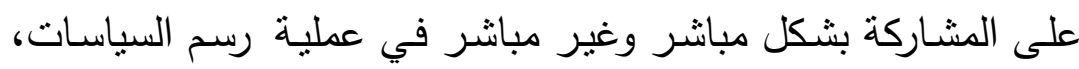

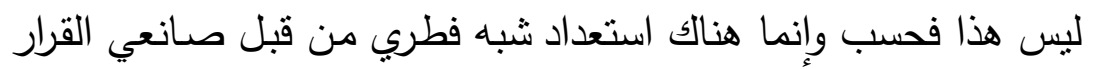

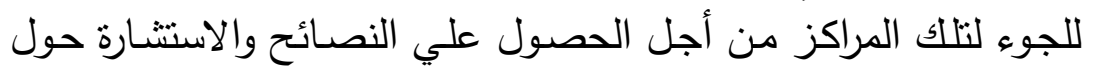
موضوعات السياسة الخارجية والمحلية. 
r- تعد المراكز البحثية في الولايـات المتحدة الأمريكية من أبرز سمات

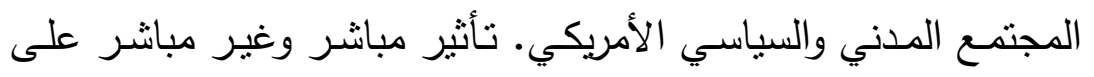

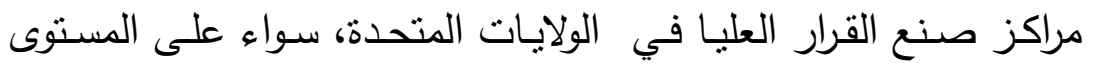

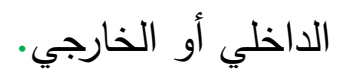

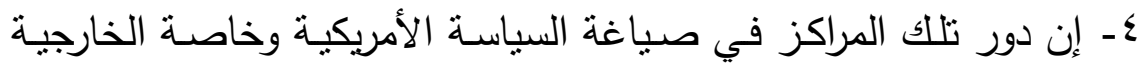

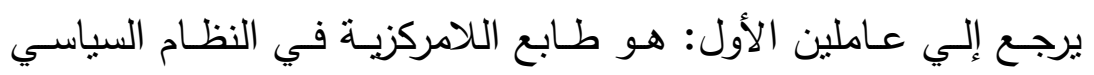

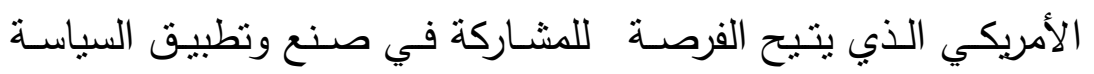
الخارجيـة بطرق مباشرة وغير مباشرة، وبما لايجعل السياسـة الخارجية حكرا على مؤسسة دون الأخرى.

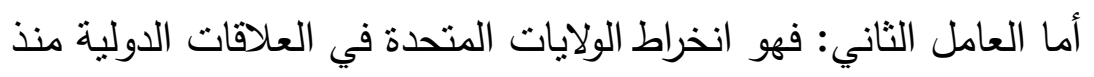

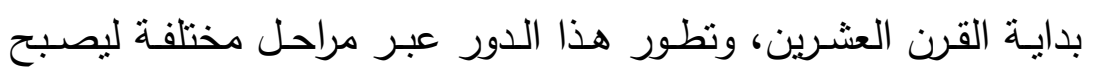
فاعل رئيس. 0ـ تتخخل المراكز البحثية الأمريكية ندخلاً مباشراً في بعض القضايا الدولية

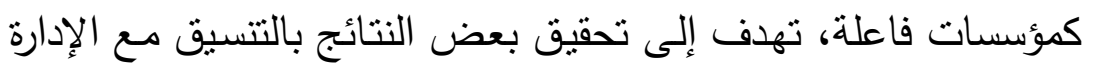

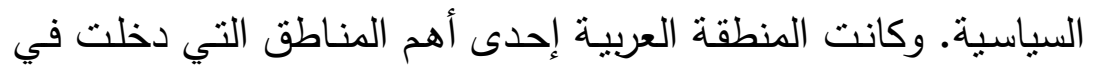
هعظم البرامج البحثية لأكثر المراكز البحثية الأمريكية.

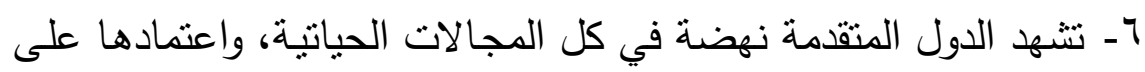

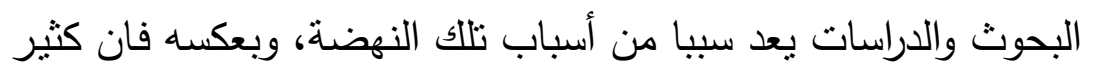

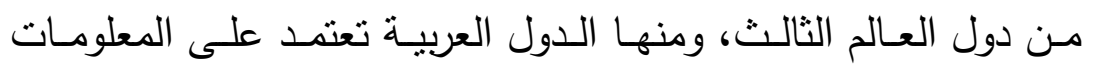
الإستخبارية وعلى وزارات الداخلية والمباحث العامة أكثر من اعنى اعتمادها

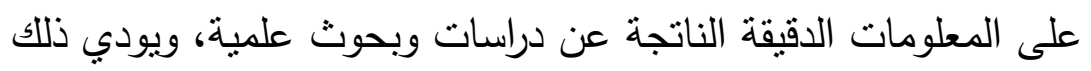

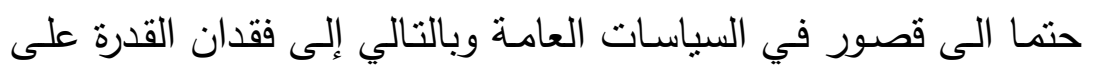
الإبداع والإقناع. V- ساهم الإعلام في إبراز دور المراكز البحثية في العقود المتأخرة واستفاد

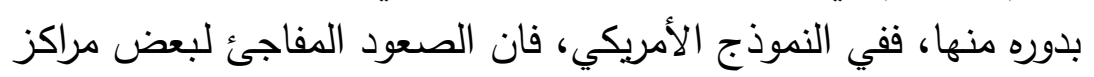




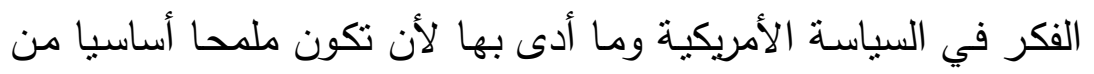

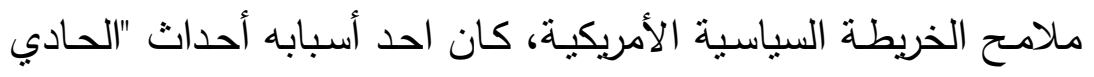

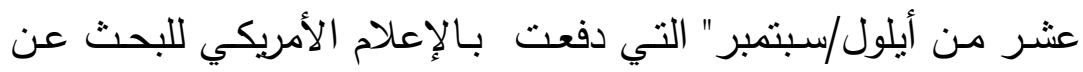

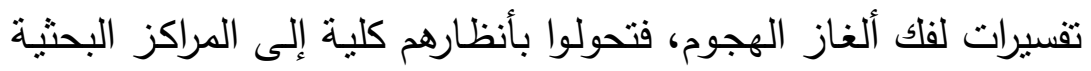

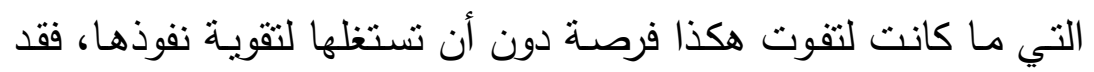

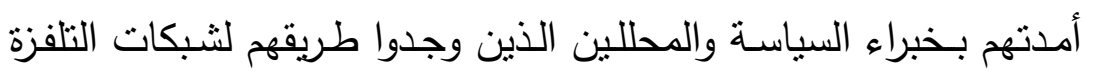
والجرائد الكبرى وأصبحوا يتمتعون بظهور إعلامي مكتئ. 1- إن معرفة كيفية تبلور المواقف والقرارات السياسية الأمريكية يسهر كثئرا

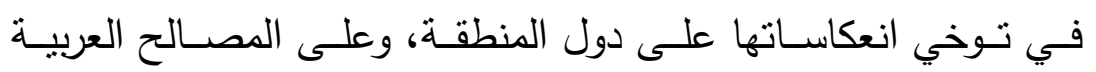

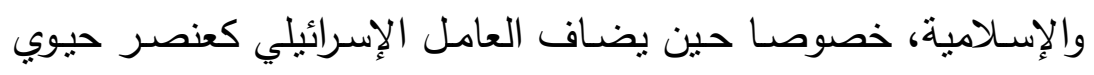

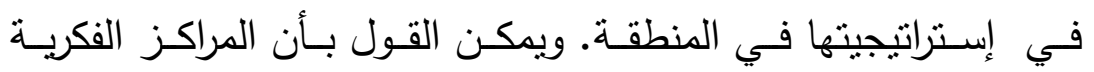

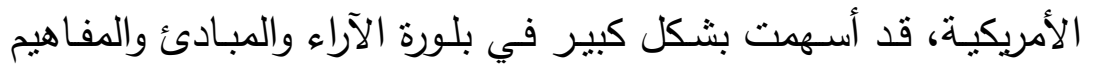

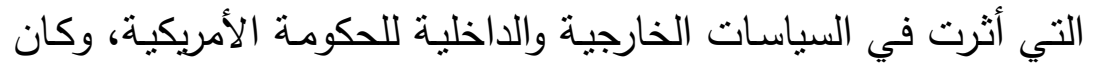

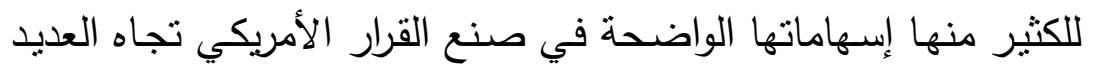

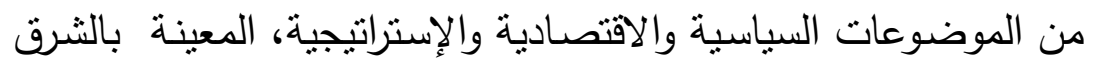

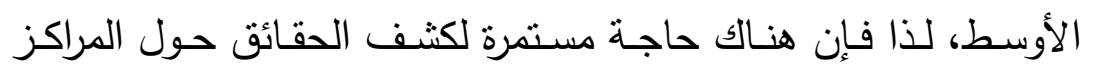

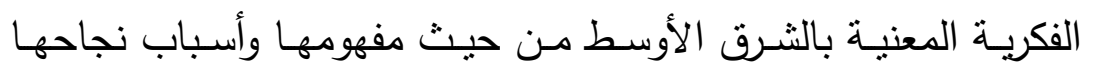
وأدوات وأساليب تأثيرها.

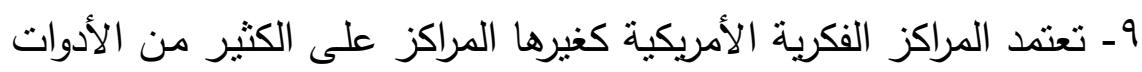

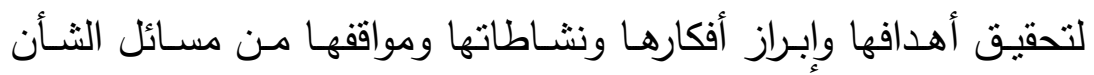

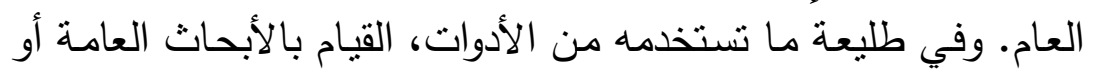

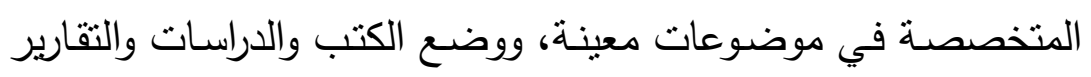

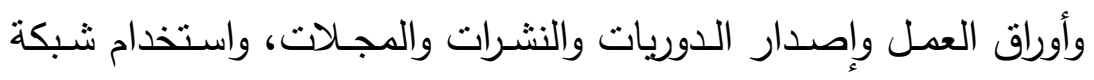

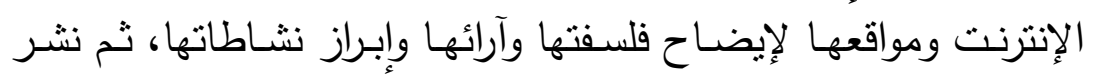
الآراء والمقالات في الدوريات العلميـة والمجـلات. كذللك تقوم المراكز 
بعقد المؤتمرات والمنتديات والندوات والمحاضرات وورش العمل وبرامج

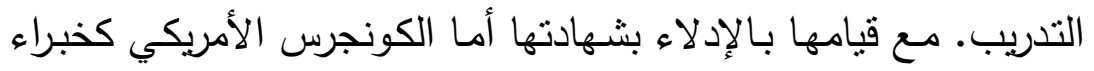
ومتخصصين في الموضوعات التي يبحنها.

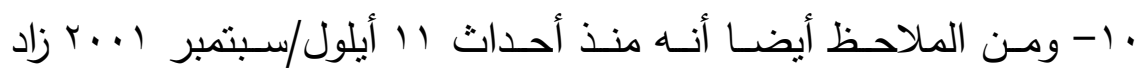
ظهور الآراء المعاديـة للعرب والمسلمين بمقدار ازدياد تأثثر المراكز

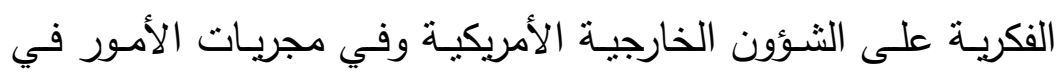

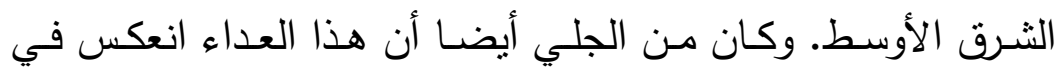

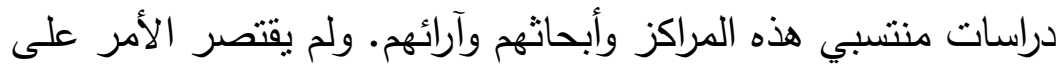

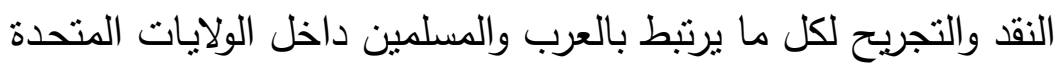

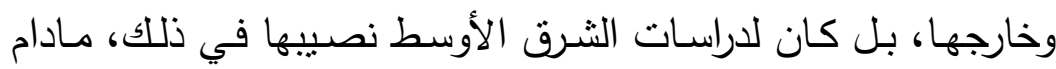

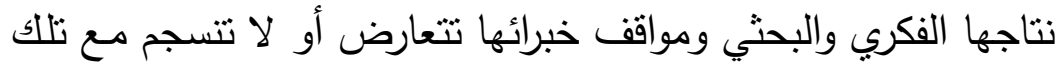

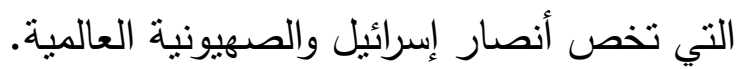

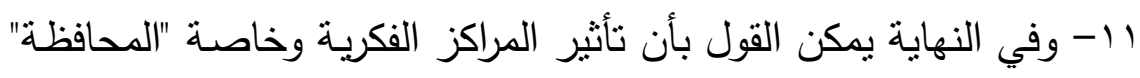

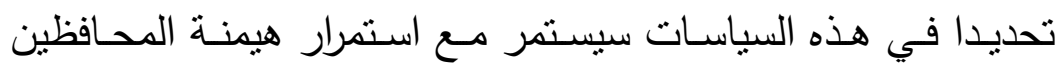

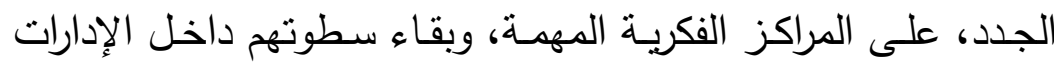

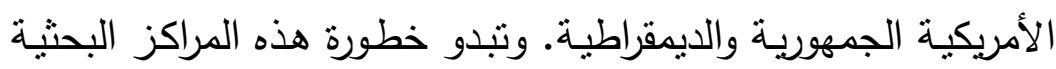

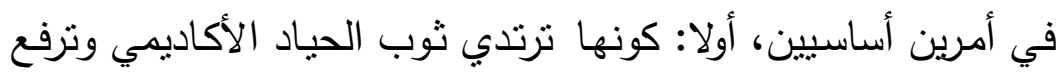

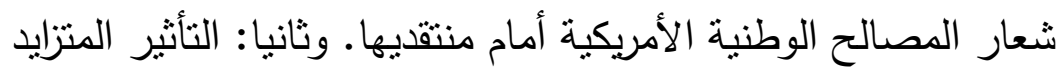

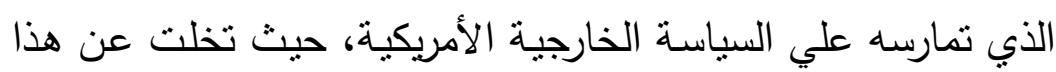

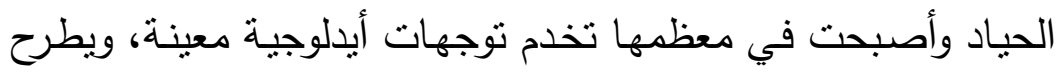

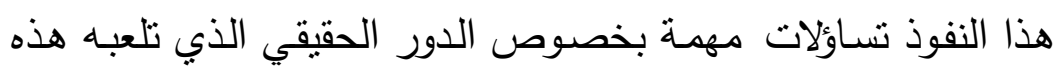




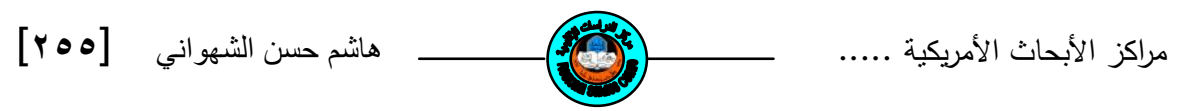

\author{
American Think-Tank and their Impact on the \\ American Foreign Policy Toward Arab Matters \\ Hashim Hasan Husein ALShahwani \\ Historical and Cultural Studies Dept. Regional Studies Center \\ University of Masul
}

\begin{abstract}
Absract
Think-Tanks have emerged in the beginning of the $20^{\text {th }}$ century and have taken their ideal form in the U.S.A where they have attained great attention of the policy makers. It is commonly that these thinktanks are entrusted with doing studies for dealing with important political and strategic issues and projects.

The research treats with the nature of these Think-Tanks, their divisions and the map of their existence and programs, and aims at difining the formulas during which they impact policy making especially in foreign policy and its consequences in relation to Arab region and its impact on American policy.
\end{abstract}




$$
\text { (') فؤاد علي بكر علي، المراكز البحثية ودورها في التنمية والاستقرار، على الموقع: }
$$

http://fab83.maktoobblog.com/1561119/

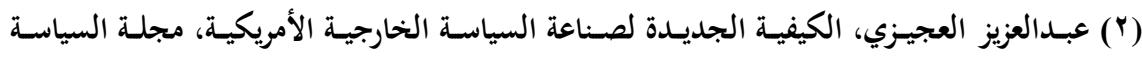

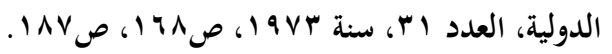

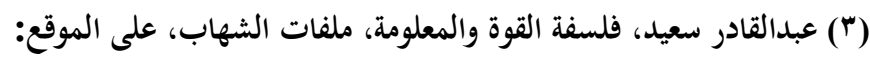

http://www.chihab.net/modules.php?name=News\&file=print\&sid=1196

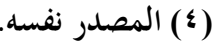

$$
\text { (0) أميمه عبداللطيف، قراءة في خرائط مراكز الفكر الأمريكية، على الموقع: }
$$

http://www.saudiinfocus.com/ar/forum/showthread.php?p=6656

هناك مهام كثيرة تنهض بها مراكز البحث الأمريكية يمكن ذكر أهمها ا- توليد أفكار وخيارات

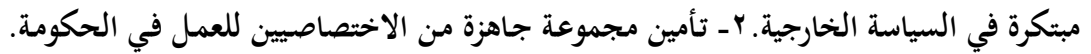

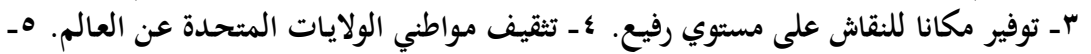

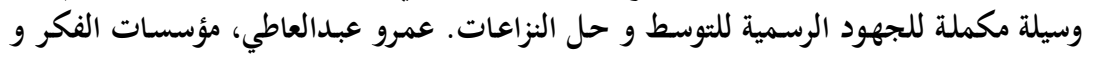

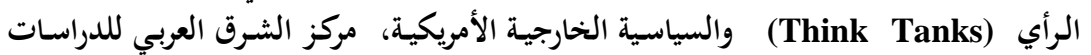
الإستراتيجية والحضارية على الموقع:

http://www.al-erada.com/vb/showthread.php?2957-

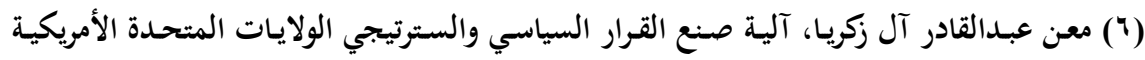

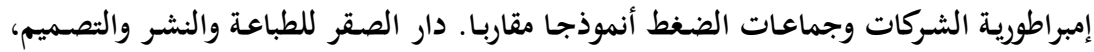

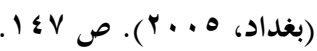

$$
\text { ( أثر المراكز الفكرية على السياسة الخارجية الأمريكية، على الموقع: (V) }
$$

http://www.tawhed.ws/r?i=thinking

(^) مراكز البحوث وصناعة التغيير مطابخ لصناعة القرار وخلايا تفكير للابداع، مركز النبأ الوثائقي-

$$
\text { ملف تخصصي، على الموقع: }
$$

http://www.annabaa.org/nbanews/2009/06/100.htm.

$$
\text { (9) المراكز الفكرية بأمريكا.. الظاهرة والدور والتأثير، مركز النخبة للدراسات على الموقع: }
$$

http://www.islamonline.net/servlet/Satellite?c=ArticleA C\&cid=1212925311050\&pa

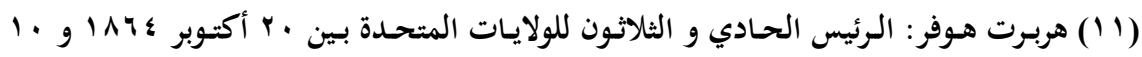

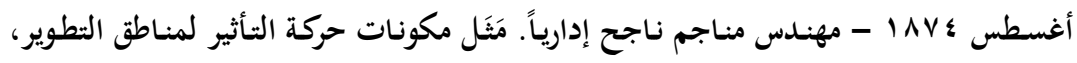


محاورا ذكيا في ايجاد الحلول التقنية شبه الهندسية للمشاكل الاجتماعية و الاقتصادية، الأمر

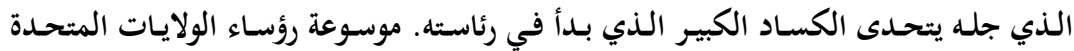

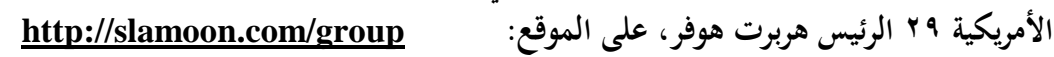

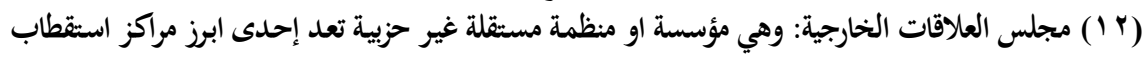

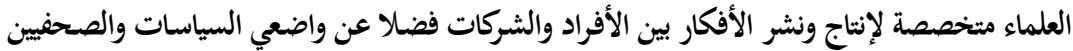

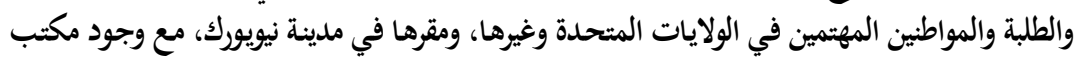

The Council on Foreign Relations.

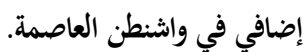

http://www.unc.edu/ Itolles/illuminati/cfr.html

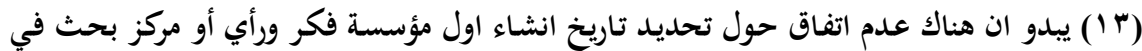

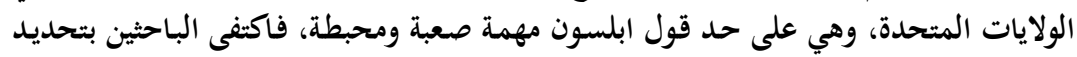

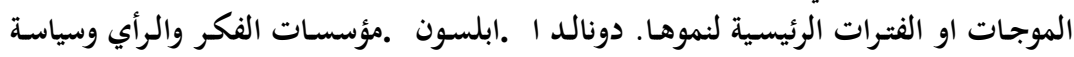
الولايات المتحدة ألأمريكية نظرة تاريخية على الموقع التالي:

http:/www.usinfo.state.gov/journals/itps/1102/ijpa/Abelson

$$
\begin{aligned}
& \text { (؛ (1) (1) المصدر نفسه. } \\
& \text { (10) } \\
& \text { (17) } \\
& \text { (IV) (IV) سعيد، المصدر السابق. (IV) } \\
& \text { (I^) باسم خفاجي، أثر المراكز الفكرية على السياسة الخارجية الأمريكية. على الموقع: }
\end{aligned}
$$

http://www.aljaredah.com/paper.php?source=akbar\&page=3

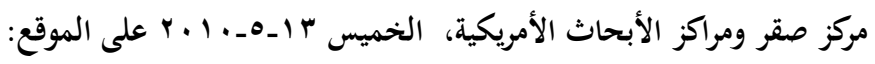

\section{http://www.Saqr Centre for Strategic Studies}

(·•) مجلس العلاقات الخارجية: (Council on Foreign Relations)، وهو مركز أبحاث

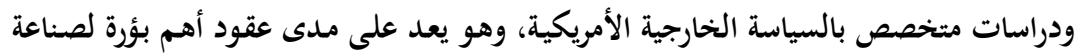

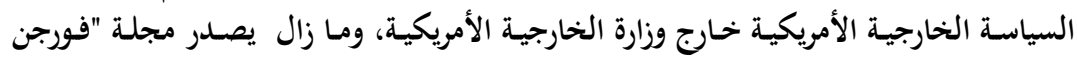

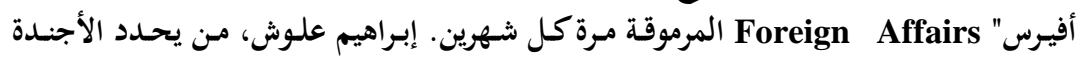

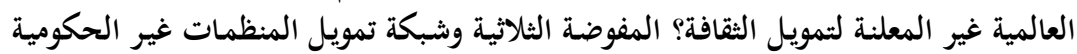

$$
\text { ومراكز الأبحاث على الموقع: }
$$

http://www.freearabvoice.org/arabi/magalat/alMofadevvehAltholathevveh.htm

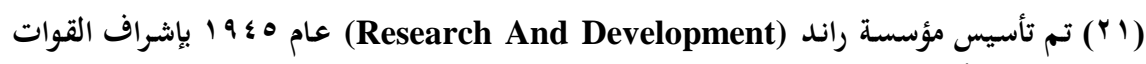

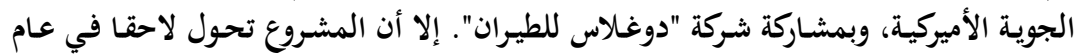

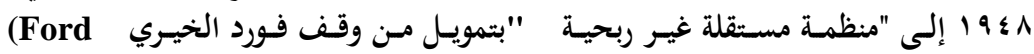
Foundation). 
بالمعلومات والتحليلات اللازمة" إلا أن هذا الهدف توسع لاحقاً عندما أصبحت المؤسسة شبه

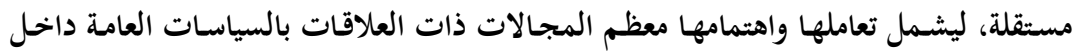

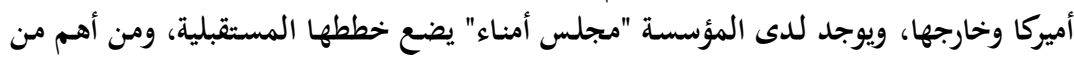

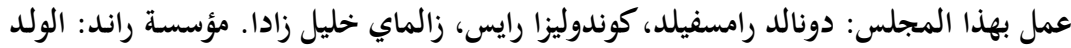
الشرعي للبنتاغون، Rand ملف حول مؤسسة راند الأمريكية، على الموقع:

http://alfetn.com/vb3/showthread.php?t=30538

$$
\text { (Yr) عبدالغفور الخطيب، صناعة القرار السياسي الأمريكي .. كيف؟ على الموقع: }
$$

http://www.horannews.com/vb/showthread.php?t=289\&page=2

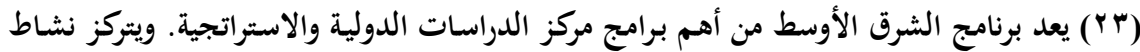

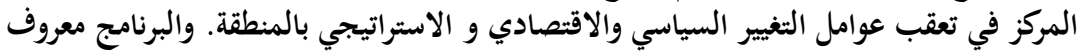

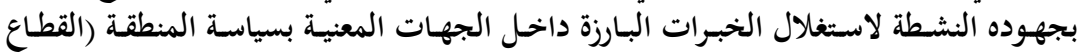

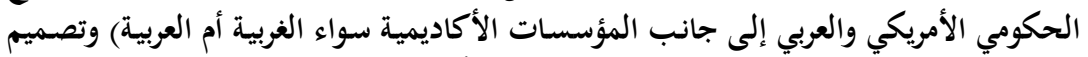

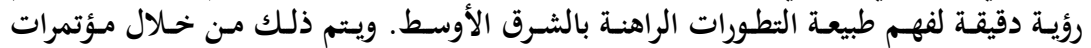

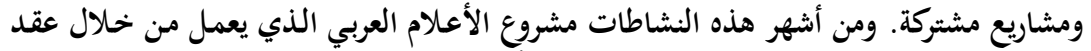

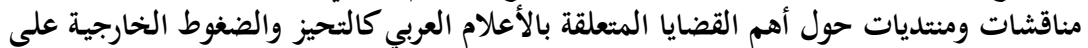

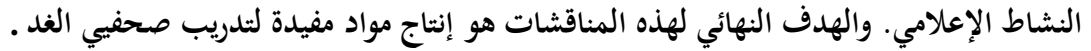

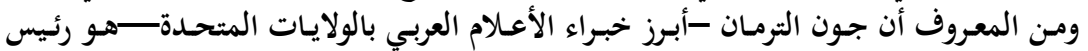

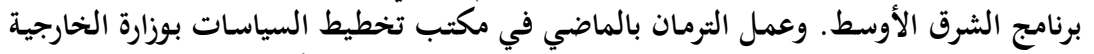

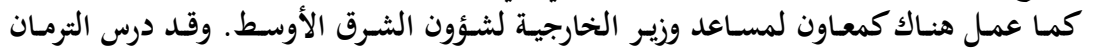

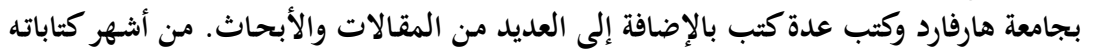

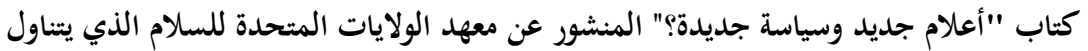

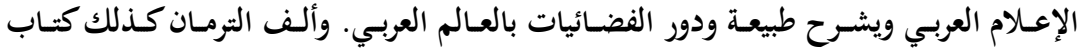
"الأحلام المحطمة: مصر والمساعدامدات الخدارجية الإدية الأمريكية. هشام سلام، مراكز الأبحاث الأمريكية...الحلقة الثانية: مركز الدراسات الداتية الدولية والاستراتجية، http://www.saudiinfocus.com/ar/forum/showthread.php?t=7604

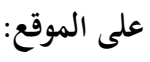

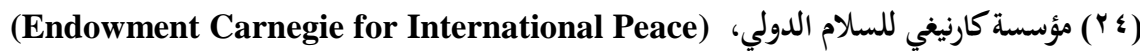
http://www.carnegieendowment.org

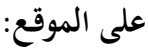

$$
\text { ( ) المراكز الفكرية بأمريكا.. الظاهرة والدور والثأثير . المصدر السابق. }
$$

(26) The Center for American and Arab Studies in Washington, http://thinktanksmonitor.com/thinkmonitor/aboutus.htm 


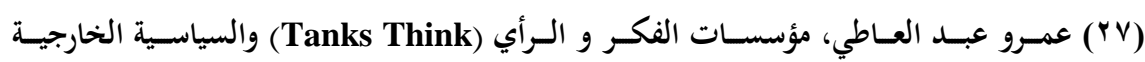

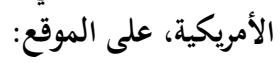

http://www.saqrcenter.net/?p=1626

$$
\begin{aligned}
& \text { (Y^) المراكز الفكرية بأمريكا، المصدر السابق. } \\
& \text { المصدر نفسه. }
\end{aligned}
$$

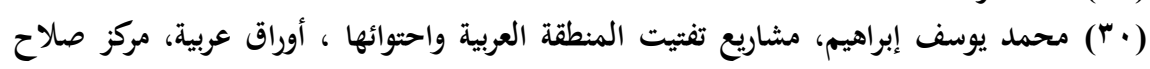

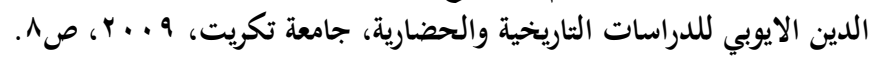

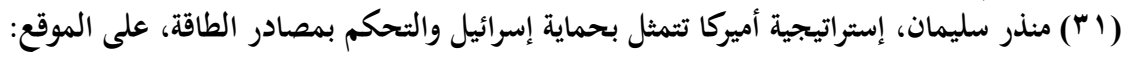
http://thawra.alwehda.gov.sy/_print_veiw.asp?FileName=99340804420060703005

$$
\text { (rY) مراكز أبحاث أمريكية: الشرق الأوسط سيشهد تحولات هذا العام، على الموقع: }
$$

http://www.albosala.com/Portals/Content/?Name=\%D9\%85\%D8

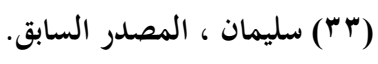

(34) Washington Institute for Near East Policy.

http://www.sourcewatch.org/index.php?

$$
\text { (T) ) مراكز التفكير أو مستودعات الأفكار (Think Tanks)، على الموقع: }
$$

http://rwafd.com/vb/t35770.html

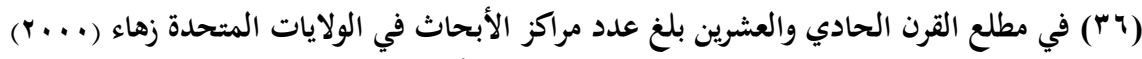

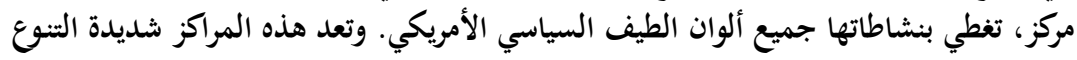

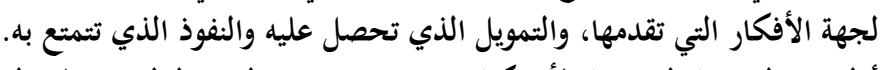

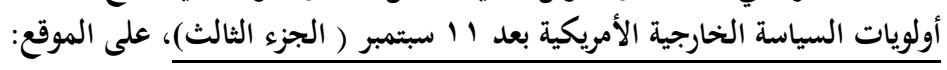

http://master2010.maktoobblog.com/441/\%D8\%A3\%D9\%88\%D9\%84\%D9\%88\%D9

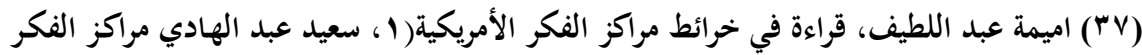

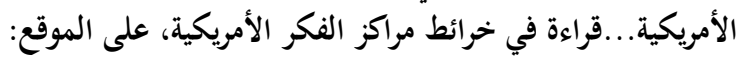

http://www.inciraq.com/pages/view_paper.php?id=200710558

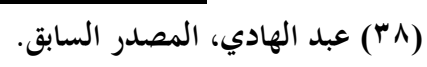

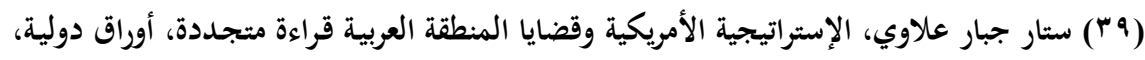

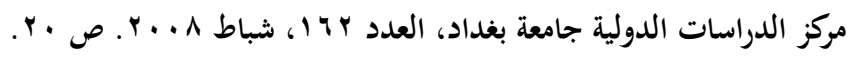

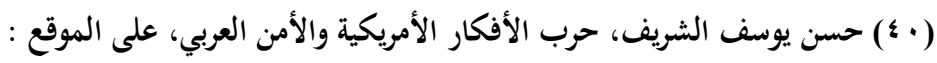

http://www.moltaqamaghagha.com/vb/showthread.php?t=

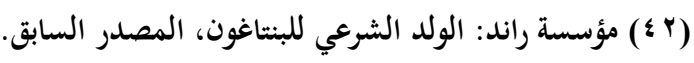


(r \&) يحيى الشاعر، من هم خبراء الشرق الأوسط الذين تؤثر آراؤهم في رسم السياسة الخارجية

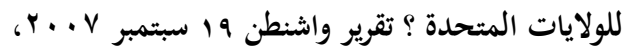

http://www.alzaytouna.net/arabic/?c=201\&a=47891

$$
\text { ( ) ( ؛ ) ابلسون، المصدر السابق. }
$$

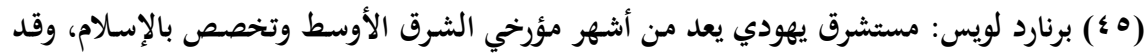

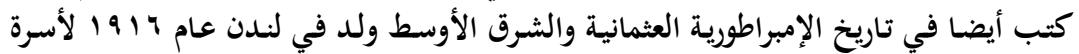

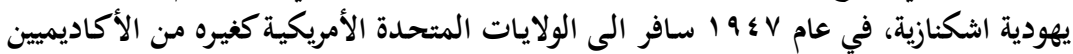

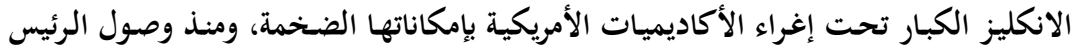

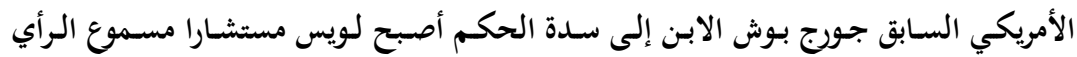

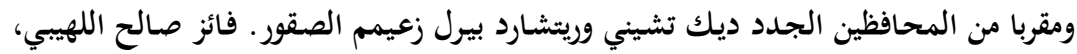

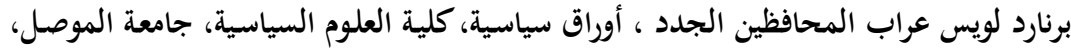

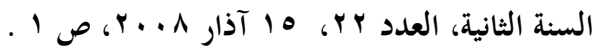

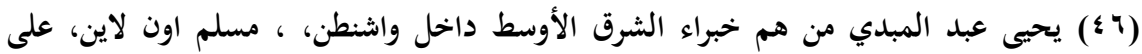

http://www.moslimonline.com/?page=artical\&id=634 ( ) ( المصدر نفسه.

(48) Brookings Institution, From Wikipedia, the free encyclopedia:

http://en.wikipedia.org/wiki/Brookings_Institution

(9 ؛ ) قراءة في خرائط مراكز الفكر الأمريكية (1) بقلم أميمة عبداللطيف 2005-21-2 ، على

الموقع: - المعلى

http://www.saudiinfocus.com/ar/forum/showthread.php?p

(• (0) تشارلس بابينغتون ودان بالتز، حزمة من الانتقادات والمطالب وضعها الديمقراطيون امام بوش،

ترجمة : يحيى عبدالمبدى، على الموقع:

http://almadapaper.net/sub/06 -p04.htm/

(51) Saban Center for Middle East Policy Brookings Institution From Wikipedia, the free encyclopedi.

http://en.wikipedia.org/wiki/Brookings_Institution

$$
\text { ( الشاعر) }
$$

$$
\text { (r) عبداللطيف، مراكز الفكر الأمريكي (r) إ): سماسرة الأفكار،على الموقع: }
$$

http://www.saudiinfocus.com/ar/forum/showthread.php?p=6656

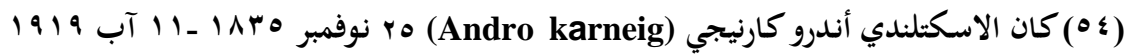

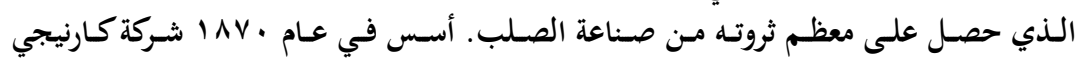


للصلب، وهي الخطوة التي عززت اسمه كواحد من "قادة الصناعة مما أعطاه فرصة لتخصيص التحي

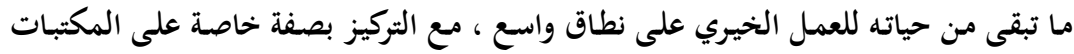

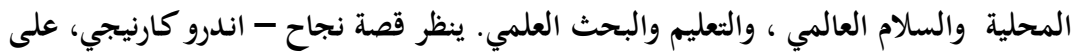

\section{http://siddig.net/inter/shakhsiat/andro/1.html}

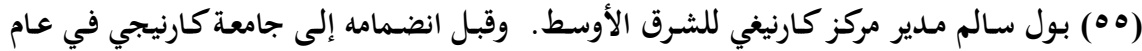

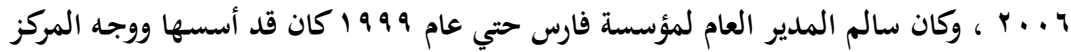

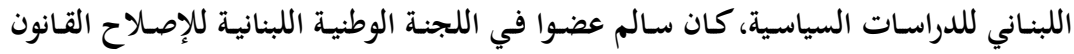

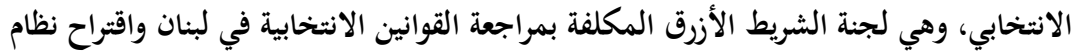

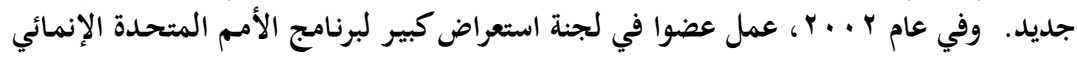

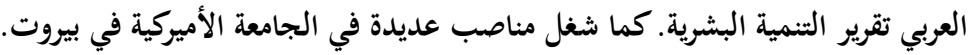

Paul Salem, Carneg endowment Middle East Center

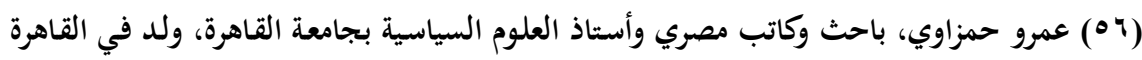

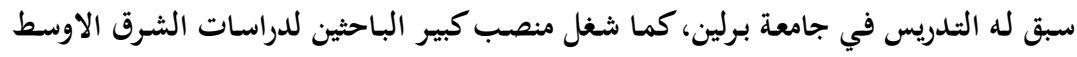

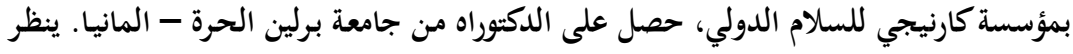

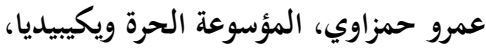

http://ar.wikipedia.org/wiki/\%D8\%B9\%D9\%85\%D8\%

$$
\text { (الشاعر، المصدر السابق. }
$$

$$
\text { (OA) ) ترجمات لمختارات من إصدارات مؤسسة كارنيغي للسلام العالمي، على الموقع: }
$$

http://www.grc.ae/?frm action=publication_detail\&frm module

$$
\text { (9 9 ( المراكز الفكرية بأمريكا.. الظاهرة والدور والتأثير، المصدر السابق. }
$$

(60) Carnegie-Middle-East-Center-Beirut,

\section{http://www.scribd.com/collections/2346743}

http://www.aei.org

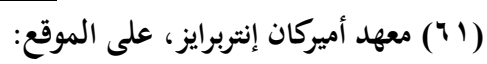

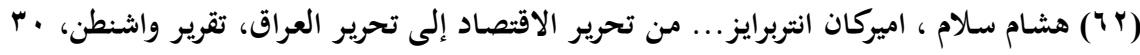
www.Taqrir.org/showarticle.cfm?id=106

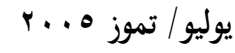

$$
\text { (rT) تحليل صنع السياسة الخارجية الأمريكية في فترة بعد الحرب الباردة يسين طرشي، }
$$

http://Yacine.maktoobblog.com/1053479

(64) American Enterprise Institute for Public Policy Research, http://topics.nytimes.com/topics/reference/timestopics/organizations/a/america (7\%) من هم خبراء الشرق الأوسط الذين تؤثر آراؤهم في رسم السياسة الخارجية للولايات المتحدة

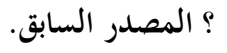




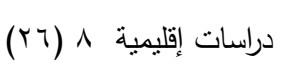

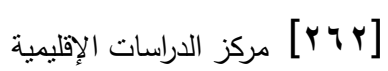

(ד (7) فؤاد علي بكر علي المراكز البحثية ودوره ا في التنمية والإستقرار، على الموقع

http://fab83.maktoobblog.com/1561119/

(67) Washington Institute for Near East Policy.

http://www.sourcewatch.org/index.php?

(^) († باسم الخفاجي، المصدر السابق. 